\title{
Article \\ ZnO Semiconductor Nanoparticles and Their Application in Photocatalytic Degradation of Various Organic Dyes
}

\author{
Priscy Alfredo Luque-Morales ${ }^{1}$, Alejandra Lopez-Peraza ${ }^{1}$, Osvaldo Jesus Nava-Olivas ${ }^{1}$, Guillermo Amaya-Parra ${ }^{1}$, \\ Yolanda Angelica Baez-Lopez ${ }^{1}$ (D), Victor Manuel Orozco-Carmona ${ }^{2, *}$, Horacio Edgardo Garrafa-Galvez ${ }^{1}$ (D) \\ and Manuel de Jesus Chinchillas-Chinchillas ${ }^{3, *}$ \\ 1 Facultad de Ingeniería, Arquitectura y Diseño, Universidad Autónoma de Baja California (UABC), \\ Ensenada 22860, Baja California, Mexico; pluque@uabc.edu.mx (P.A.L.-M.); \\ alejandra.lopez.peraza@uabc.edu.mx (A.L.-P.); navao@uabc.edu.mx (O.J.N.-O.); \\ amaya@uabc.edu.mx (G.A.-P.); yolanda@uabc.edu.mx (Y.A.B.-L.); horacio.garrafa@uabc.edu.mx (H.E.G.-G.) \\ 2 Centro de Investigación en Materiales Avanzados (CIMAV), Chihuahua 31136, Chihuahua, Mexico \\ 3 Departamento de Ingeniería y Tecnología, Universidad Autónoma de Occidente (UAdeO), \\ Guasave 81048, Sinaloa, Mexico \\ * Correspondence: victor.orozco@cimav.edu.mx (V.M.O.-C.); manuel.chinchillas@uadeo.mx (M.d.J.C.-C.)
}

check for updates

Citation: Luque-Morales, P.A.; López-Peraza, A.; Nava-Olivas, O.J.; Amaya-Parra, G.; Báez-López, Y.A.; Orozco-Carmona, V.M.;

Garrafa-Gálvez, H.E.;

Chinchillas-Chinchillas, M.d.J. ZnO Semiconductor Nanoparticles and Their Application in Photocatalytic Degradation of Various Organic Dyes. Materials 2021, 14, 7537. https:// doi.org/10.3390/ma14247537

Academic Editors: Ankica Šarić and Andrea Petrella

Received: 6 October 2021

Accepted: 27 November 2021

Published: 8 December 2021

Publisher's Note: MDPI stays neutral with regard to jurisdictional claims in published maps and institutional affiliations.

Copyright: (c) 2021 by the authors. Licensee MDPI, Basel, Switzerland. This article is an open access article distributed under the terms and conditions of the Creative Commons Attribution (CC BY) license (https:// creativecommons.org/licenses/by/ $4.0 /)$.

\begin{abstract}
The biosynthesis of oxide semiconductor nanoparticles (NPs) using materials found in nature opens a wide field of study focused on sustainability and environmental protection. Biosynthesized NPs have the capacity to eliminate organic dyes, which pollute water and cause severe damage to the environment. In the present work, the green synthesis of zinc oxide $(\mathrm{ZnO}) \mathrm{NPs}$ was carried out using Capsicum annuum var. Anaheim extract. The photocatalytic elimination of methylene blue (MB), methyl orange $(\mathrm{MO})$, and Rhodamine $\mathrm{B}(\mathrm{RhB})$ in UV radiation was evaluated. The materials were characterized by scanning and transmission electron microscopy (SEM and TEM) and SEM-coupled energy dispersive spectroscopy (EDS), attenuated total reflectance-infrared (ATR-IR), X-ray photoelectron spectroscopy (XPS), X-ray diffraction (XRD), Photoluminescence (PL), and ultraviolet-visible spectroscopy (UV-Vis). The TEM analysis showed the NPs have an average size of $40 \mathrm{~nm}$ and quasi-spherical shape. ATR-IR showed the ZnO NPs contained functional groups from the extract. The analysis through XRD indicated that the NPs have a hexagonal zincite crystal structure with an average crystallite size of approximately $17 \mathrm{~nm}$. The photoluminescence spectrum (PL) presented an emission band at $402 \mathrm{~nm}$. From the UV-Vis spectra and TAUC model, the band-gap value was found to be $2.93 \mathrm{eV}$. Finally, the photocatalytic assessment proved the ZnO NPs achieved $100 \%$ elimination of $\mathrm{MB}$ at $60 \mathrm{~min}$ exposure, and 85 and $92 \%$ degradation of $\mathrm{MO}$ and $\mathrm{RhB}$, respectively, at $180 \mathrm{~min}$. This indicates that ZnO NPs, in addition to using a friendly method for their synthesis, manage to have excellent photocatalytic activity in the degradation of various organic pollutants.
\end{abstract}

Keywords: biosynthesis; Capsicum annuum var. Anaheim; organic dye; photocatalysis; ZnO nanoparticles

\section{Introduction}

Environmental pollution is a topic of interest to the scientific community, as the increase in damage caused to ecosystems is becoming more noticeable. Water is an essential natural resource for life on the planet; however, the lack of awareness from society and the high percentage of pollution in water systems (rivers, seas, streams, etc.) brought about by industrial processes generates eutrophication, consumes oxygen from water and causes the death of living species that inhabit these ecosystems (flora and fauna) [1]. Therefore, it is important to deepen research to minimize these problems, or to find alternatives to eliminate pollutants (environmental remediation) [2]. Within the wide classification of waste generated by industries around the world, organic dyes are of great concern, as they are resistant to biodegradation and prevent the penetration of sunlight into water, causing negative effects on photosynthesis [3]. Furthermore, organic dyes 
have chemical compositions that, for the most part, have turned out to be very stable, resistant, toxic, potentially mutagenic, and carcinogenic [4]. These dyes are used in the pharmaceutical, food, cosmetic, plastic, paper, and textile industries. The textile industry causes the highest levels of water pollution. The existence of around 10,000 colorants has been reported, of which approximately 700,000 tons are generated per year [5-7]. Some techniques used for the elimination of organic dyes, pollutants, and non-biodegradable residues in water are ion exchange, adsorption, ozonation, Fenton reaction, reductive degradation, and microbial processes, among others [8]. However, some of these techniques are expensive, use dangerous reagents, generate toxic by-products, and do not eliminate the source of the problem [9]. Amid the techniques used, photocatalysis is a simple, lowcost process that does not cause toxic by-products. This technique has been shown to be highly effective in degrading pollutants in water using solar energy or UV energy. In 2021, J. Yin et.al. synthesized polyvinylidene fluoride (PVDF) and titanium dioxide $\left(\mathrm{TiO}_{2}\right)$ membranes for the photocatalytic degradation of $\mathrm{MO}$, achieving $95 \%$ degradation in $200 \mathrm{~min}$ [10]. Furthermore, Al-Gharibi et.al. synthesized a silver nanoparticle (Au$\mathrm{NPs}$ ) and zinc oxide nanorod (ZnO-NRs) composite, and used it with sunlight-assisted photocatalysis to degrade $92 \%$ of contaminating paracetamol within $4 \mathrm{~h}$ [11].

In the photocatalytic process, a photocatalyst is used, which generally is a semiconductor material that, by absorbing photons, is activated to produce hydroxyl radicals (oxidant) and thus helps the total degradation of organic dyes [12]. The photocatalysts mostly used today are oxide semiconductor NPs, such as titanium dioxide $\left(\mathrm{TiO}_{2}\right)$, tin dioxide $\left(\mathrm{SnO}_{2}\right)$, copper oxide $(\mathrm{CuO})$, iron oxide (III) $\left(\mathrm{Fe}_{2} \mathrm{O}_{3}\right)$, wolfram oxide $\left(\mathrm{WO}_{3}\right), \mathrm{ZnO}$, etc. [13-18]. $\mathrm{ZnO}$ is a material with excellent thermal stability and is a multifunctional material. It has been used in applications such as luminescent material, sensors, solar cells, batteries, optoelectronic applications and with good results in photocatalysis; in fact, it is considered one of the best photocatalysts for the degradation of pollutants in water [19]. $\mathrm{ZnO}$ NPs have a favorable band-gap of around $3.37 \mathrm{eV}$, have strong oxidizing and non-toxic nature, excellent chemical and mechanical stability, and have shown to be photosensitive, leading to their use in various applications [20]. There are various techniques for the synthesis of these NPs, some related to the top-down approach (atomization, laser ablation, radiofrequency, sputtering, etc.) and others related to the bottom-up approach (sol gel process, template synthesis, electro-deposition, microwave-assisted synthesis, etc.) [21-24]. Unfortunately, most of these techniques impose a series of drawbacks, such as high cost, use of organic solvents, toxic stabilizing agents, toxic by-products, and most are highly reactive and harmful to the environment [25]. The current research challenge is to apply synthesis methods that are more environmentally friendly, and to use them to obtain oxide semiconductor-based NPs. One such method is green synthesis, which consists in using materials found in nature (biologic materials). Such methods help to improve processes that are compatible with the environment, makes them cheaper, safer, faster, simpler, use ecologic agents, and produce fewer harmful by-products [26]. Among the investigations that have reported the use of green synthesis are those by P.A. Luque, et.al. in 2021, where he used Camellia sinensis to obtain $\mathrm{SnO}_{2} \mathrm{NPs}$ of $4.7 \mathrm{~nm}$ particle size [27]. On the other hand, Ghulam Nabi et.al., in 2020, used lemon peel extract to biosynthesize $\mathrm{TiO}_{2} \mathrm{NPs}$, achieving particle sizes of 80-140 nm, and quasi-spherical shape [28]. Furthermore, K. Velsankar, et.al., in 2020, used Allium sativum extract for the biosynthesis of CuO NPs, achieving particle sizes of 20-40 nm [29]. Furthermore, biosynthesized NPs have already been used for the photocatalytic degradation of organic dyes. M. Aravind et.al. synthesized Au-NPs using Jasmine flower extract in 2021, and used them to degrade $78 \%$ of contaminating MB within $120 \mathrm{~min}$ [30]. On the other hand, L. Ardakani et.al. synthesized iron NPs (Fe-NPs) using Chlorophytumcomosum extract in 2021, presenting a 77\% degradation of MO within $6 \mathrm{~h}$ [31]. S. Rajendrachari et.al., also in 2021, used cauliflower to biosynthesize $\mathrm{ZnO} N \mathrm{Ns}$, managing to degrade $75 \% \mathrm{RhB}$ within $2 \mathrm{~h}$ [32]. As has been disclosed in the literature, various natural stabilizing agents have been used, such as roots, leaves, fruits, and vegetables [33]; however, what has been seldom studied is the use of chili peppers in 
the green synthesis of ZnO NPs. Specifically, the use of Anaheim Chili (Capsicum annuum var. Anaheim) has not been reported on for the biosynthesis of NPs. This material contains flavonoids, ascorbic acid, polyphenols, and capsaicin in its molecular composition, which makes it an important candidate to be used in the green synthesis of NPs [34,35]. In this research, the green synthesis of ZnO NPs was carried out using an extract of Capsicum annuum var. Anaheim. The biosynthesized NPs were characterized by SEM/EDS, TEM, ATR-IR, XRD, PL and UV-Vis. In addition, through UV-Vis, the photocatalytic activity of these NPs was evaluated for the elimination of three pollutants in water (MB, MO and $\mathrm{RhB})$.

\section{Materials and Methods}

\subsection{Materials}

For the green synthesis, the following were used: fresh Anaheim chili (Capsicum annuum var. Anaheim) acquired locally; $98 \%$ pure zinc nitrate $\left(\mathrm{Zn}\left(\mathrm{NO}_{3}\right)_{2} \bullet 6 \mathrm{H}_{2} \mathrm{O}\right)$ purchased from Sigma Aldrich, Toluca, México (CAS number 10196-18-6); deionized water with a $\mathrm{pH}$ of $7.2 \pm 0.2$. For the photocatalytic activity, three organic dyes acquired from Fagalab, Mocorito, México were used: MB (Mw. Of $373.9 \mathrm{~g} / \mathrm{mol}, 99 \%$ purity, CAS number 61-73-4); MO (Mw. $327.34 \mathrm{~g} / \mathrm{mol}, 95 \%$ purity, CAS number 547-58-0); RhB (Mw. Of $479.01 \mathrm{~g} / \mathrm{mol}$, 95\% purity, CAS number 81-88-9).

\subsection{Extract Preparation}

For the preparation of the Capsicum annuum var. Anaheim extract, $1 \mathrm{~g}$ of chili was added to $50 \mathrm{~mL}$ deionized water and stirred for $2 \mathrm{~h}$ at room temperature. Subsequently, the solution was placed in a thermal bath for $1 \mathrm{~h}$ at $60^{\circ} \mathrm{C}$. Finally, the solution was filtered with a vacuum pump using a \#4 Whatman filter. The extract was stored to be use later on in the biosynthesis process.

\subsection{Green Synthesis of ZnO NPs}

For the biosynthesis of the $\mathrm{ZnO} N P s, 2 \mathrm{~g}$ of $\mathrm{Zn}\left(\mathrm{NO}_{3}\right)_{2} \bullet 6 \mathrm{H}_{2} \mathrm{O}$ was added to $50 \mathrm{~mL}$ of Capsicum annuum var. Anaheim extract, and subjected to magnetic stirring in darkness for 1 $\mathrm{h}$ at room temperature. Subsequently, the solution was placed in thermal bath for $16 \mathrm{~h}$ at $60{ }^{\circ} \mathrm{C}$. After that time, the solution acquired a plastic consistency. The sample was placed in a porcelain capsule and heat-treated in a Thermolyne oven, model Furnace 48000, in an air environment, with a heating gradient of $100{ }^{\circ} \mathrm{C} / 5 \mathrm{~min}$ up to $400{ }^{\circ} \mathrm{C}$; it was further treated at this temperature for an additional hour. Finally, the resulting material was cooled down, manually ground, and stored.

\subsection{Photocatalytic Activity}

For the photocatalytic activity assessment, three solutions corresponding to the three organic dyes being studied were prepared to a concentration of $15 \mathrm{mg} / \mathrm{L}$ in $50 \mathrm{~mL}$ of deionized water. Subsequently, $50 \mathrm{mg}$ of photocatalyst (ZnO NPs) were added to each of the contaminated solutions (1:1 ratio), and they were stirred in darkness for 30 min until adsorption-desorption equilibrium was reached. Afterwards, the solutions were placed in reactors with UV light lamps (Polaris UV-1C, equipped with a $10 \mathrm{~W}$ bulb and $18 \mathrm{~mJ} / \mathrm{cm}^{2}$ energy) to monitor dye degradation during $3 \mathrm{~h}$ of exposure time. Over the course of the first hour, samples were obtained every $10 \mathrm{~min}$. During the second hour, degradation was evaluated every $20 \mathrm{~min}$. Finally, over the third hour of study, the samples were analyzed every $30 \mathrm{~min}$.

\subsection{ZnO NPs Characterization}

The morphology of the ZnO NPs was analyzed via SEM using a JEOL JSM-5300 scanning electron microscope, at a working distance of $11 \mathrm{~mm}$ and a voltage of $15 \mathrm{kV}$. The elemental composition was performed via EDS coupled to the SEM equipment, using Aztec software (Oxford). The TEM analysis was performed with a JEOL JEM-2010F transmission 
electron microscope, with an acceleration of $120 \mathrm{kV}$. The structural analysis of the $\mathrm{ZnO}$ NPs was performed using an ATR-IR piece of equipment (Perkin Elmer Brand, $0.5 \mathrm{~cm}^{-1}$ resolution and 400 to $3500 \mathrm{~cm}^{-1}$ measurement range) and via XRD (Bruker-D2 Phase, with a radiation of $\mathrm{Cu} \mathrm{Ka}=1.541 \AA$ at a step of 0.022 from 10 to $\left.80^{\circ}\right)$. For the elemental chemical analysis, an XPS system (Axis-Ultra, Kratos, in SPECS system using Al K $\alpha$ monochromatic X-rays at $1486.6 \mathrm{eV}$ ) was used. To evaluate the optical properties of the NPs, the PL (Horiba Nanlog, using ethanol as solvent and a concentration of $100 \mathrm{ppm}$ ) and UV-Vis (Perkin Elmer brand spectrophotometer, Lambda 365 with a wavelength of 190-800 nm, and a scanning speed of $600 \mathrm{~nm} / \mathrm{s}$ ) spectra were analyzed.

\section{Results and Discussion}

\subsection{Nanoparticles}

\subsubsection{SEM/EDS}

The morphology of ZnO NPs biosynthesized with Capsicum annuum var. Anaheim is observed in Figure 1, where certain crystal agglomerates separated from each other are observed, but, when zooming in on the micrograph (Figure 1b), it is possible to observe the different zones of agglomerates of $\mathrm{ZnO}$ NPs of different sizes and quasi-spherical shape. This is an indication of the successful formation of the nanomaterial. Morphologies very similar to those presented in this investigation have been reported in the literature [36,37]. In addition, the EDS analysis in Figure 1c depicts the percentage of the elements present in the NPs. As observed in the results, the only elements found in the material were $\mathrm{C}, \mathrm{O}$, and $\mathrm{Zn}$, which correspond to elements present in the organic molecules of the extract and to the zinc oxide NPs [38].
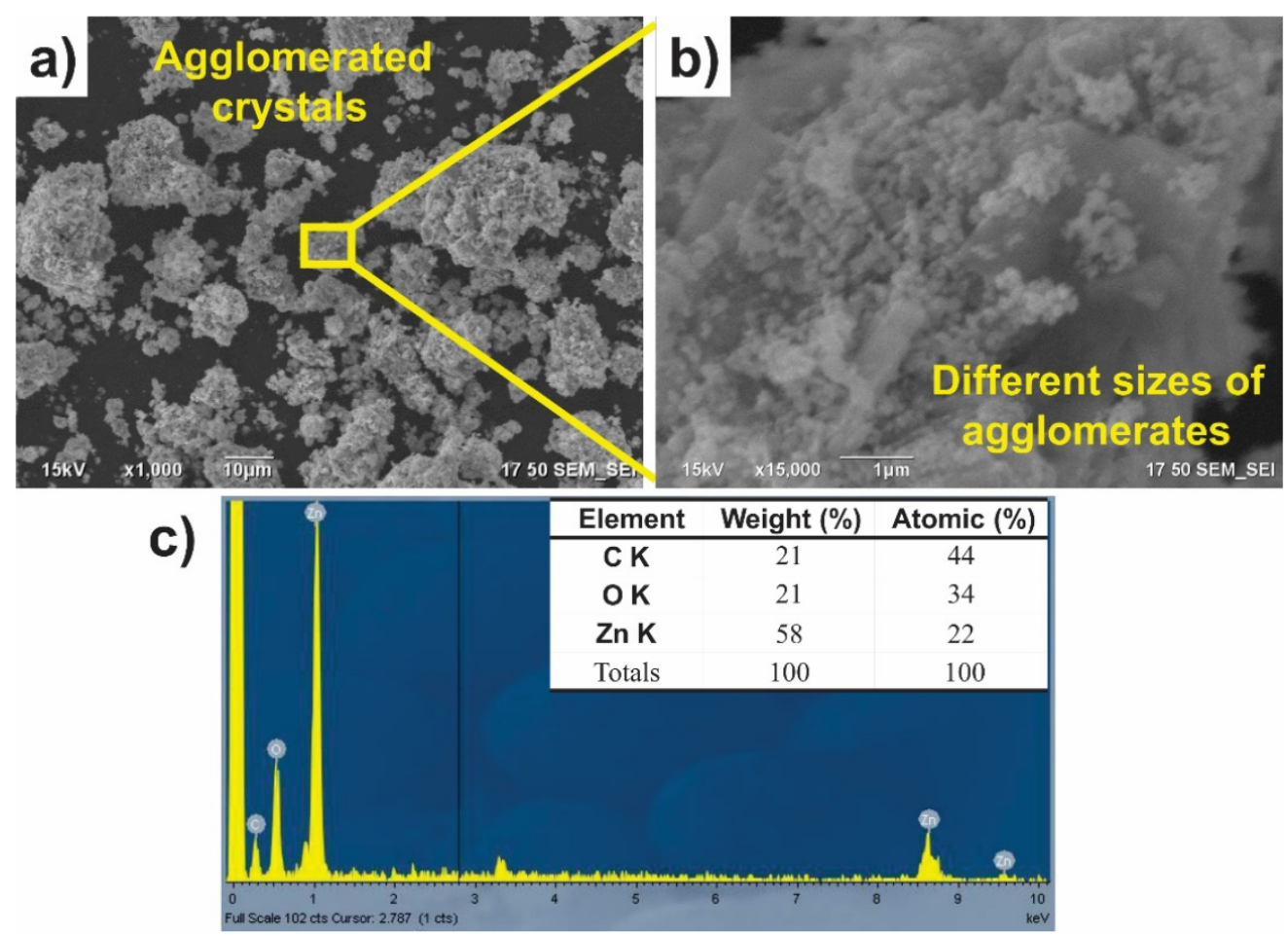

Figure 1. SEM/EDS of ZnO NPs biosynthesized with Capsicum annuum var. Anaheim. (a,b) Agglomeration of nanoparticles and (c) EDS analysis.

\subsubsection{TEM}

The morphology of the ZnO NPs biosynthesized by Capsicum annuum var. Anaheim is seen in Figure 2. Figure 2a shows that NPs have a quasi-spherical shape and showed different growths. There are NPs of different sizes $(65,47,33 \mathrm{~nm}$ etc.) and shapes (circular, oval, elongated, irregular, etc.). The measurement frequency presented a nanoparticle 
average size of $40 \mathrm{~nm}$ in 100 measurements, where sizes ranging between 20 and $50 \mathrm{~nm}$ were recorded (Figure $2 \mathrm{~b}$ ). A very similar size has previously been reported for $\mathrm{ZnO}$ NPs biosynthesized with another stabilizing agent $[39,40]$. By zooming in on the image (Figure 2c), the boundaries between the biosynthesized NPs become distinguishable. This border or edge demonstrates the separation of NPs, which denotes that the stabilizing agent accomplished its purpose. Additionally, in Figure $2 \mathrm{~d}$, the fingerprint crystalline planes can be observed and the interplanar distance can be measured, which oscillates around $0.3 \mathrm{~nm}$. This distance was measured between the planes that correspond to (100), which was verified by XRD [41].

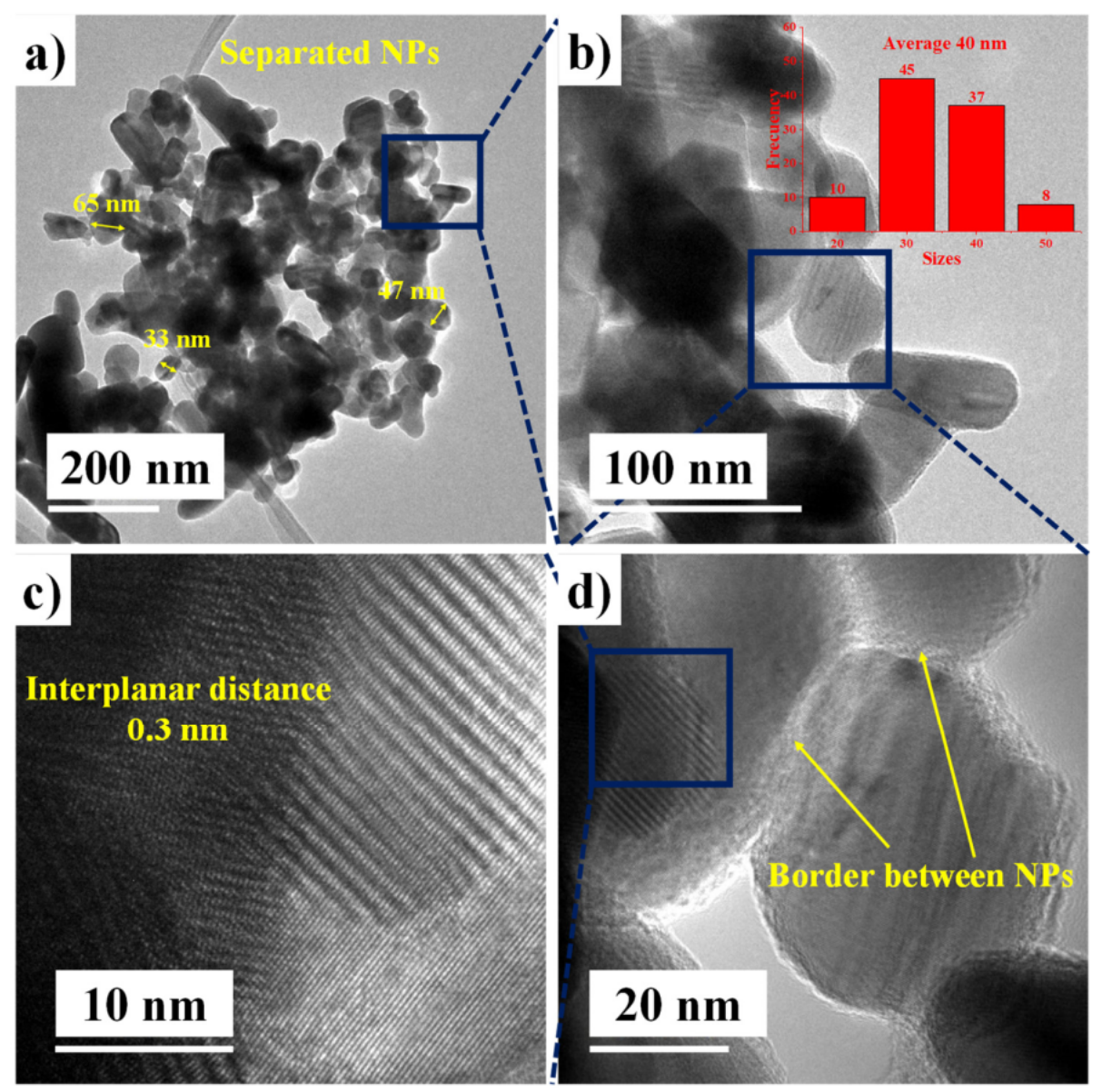

Figure 2. TEM analysis of ZnO NPs biosynthesized with Capsicum annuum var. Anaheim. (a) Morphology of the NPs, (b) size distribution, (c) interplanar distance and (d) border between NPs.

\subsubsection{ATR-IR}

The ATR-IR spectrum of ZnO NPs biosynthesized with Capsicum annuum var. Anaheim is shown in Figure 3. The analysis was performed in a frequency range of $4000-300 \mathrm{~cm}^{-1}$, at room temperature. In the spectrum, different bands can be identified, which are found in the region of $1600-800 \mathrm{~cm}^{-1}$; These bands correspond to the organic content and phenolic groups within the samples belonging to the extracts of Capsicum annuum var. Anaheim [42]. The bands observed at $861 \mathrm{~cm}^{-1}$ could be assigned to the functional groups $\mathrm{C}-\mathrm{H}$ (aromatic). The absorption peak at $1378 \mathrm{~cm}^{-1}$ can be attributed to the vibration of the C-N bonds of the alkaloids present in the Anaheim pepper [43]. The spectrum presented a band around $380 \mathrm{~cm}^{-1}$; this signal belongs to the $\mathrm{Zn}-\mathrm{O}$ bond, characteristic of $\mathrm{ZnO}$ NPs, which confirms the successful synthesis of ZnO NPs [44]. 


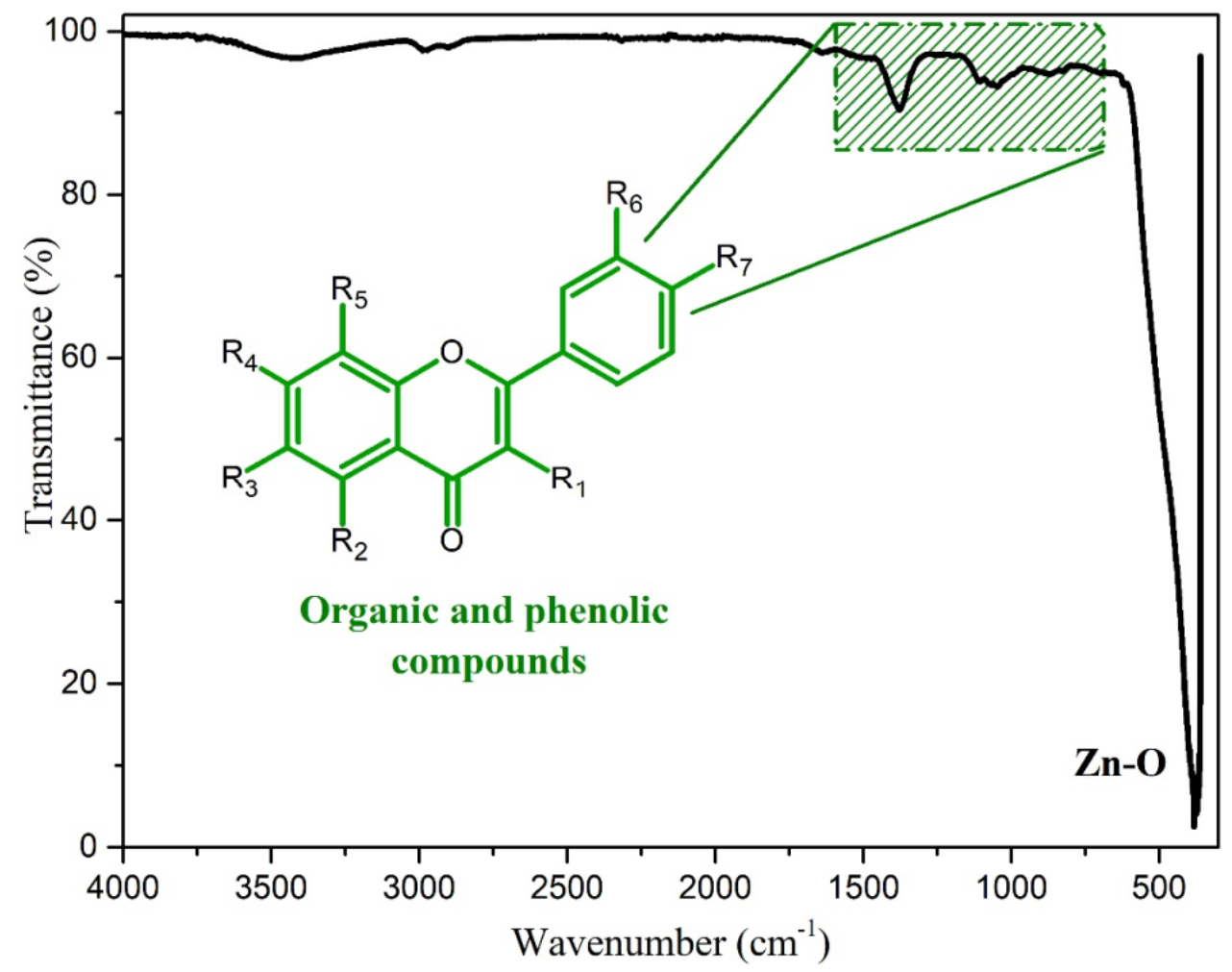

Figure 3. ATR-IR of ZnO NPs biosynthesized with Capsicum annuum var. Anaheim.

\subsubsection{XPS}

To know the elemental composition and the chemical environment of the biosynthesized NPs, an XPS analysis was carried out, which is shown in Figure 4. The energy of the spectra was calibrated with respect to the main peak, $\mathrm{C} 1 \mathrm{~s}$ at $284.5 \mathrm{eV}$ [45]. The result of the analysis of the general spectrum is shown in Figure $4 \mathrm{a}$, in the general spectrum you can see the main peaks C1s (284.5 eV), O1s (530.5 eV), and Zn2p (1022.3 and $1045.4 \mathrm{eV}$ for $Z n 2 p_{3 / 2}$ and $Z n 2 p_{1 / 2}$, respectively). The appearance of the main C1s peak confirms the presence of the organic molecules of the extract, as has been found in reports where plant extracts are used [46], while the presence of the O1s and Zn2p peaks are due to the nanoparticles [47]; the existence of only these main peaks confirms what was found by EDS, which was additionally proven by calculating the atomic percentages, equivalent to those found by the EDS technique. The percentages obtained are denoted in the inset table in Figure 4a. These results demonstrate the obtaining of ZnO NPs together with the presence of organic molecules from the Capsicum annuum var. Anaheim extract. In addition, high resolution analysis was performed for the Zn2p and O1s peaks, which are shown in Figure $4 b, c$, respectively. For the $\mathrm{Zn} 2 \mathrm{p}$ peak, a doublet was found consisting of the signals $Z n 2 p_{1 / 2}$ and $Z n 2 p_{3 / 2}$, with an energy difference of $23.1 \mathrm{eV}$ between both signals. This energy difference belongs to the $\mathrm{Zn}^{2+}$ species which is the characteristic species of $\mathrm{Zn}$ in $\mathrm{ZnO}$ NPs [48], indicating its synthesis. In the case of the O1s peak, whose maximum intensity was found at $530.5 \mathrm{eV}$, it was deconvolved into 2 signals, of which the signal that appears at $530.4 \mathrm{eV}$ belongs to the $\mathrm{Zn}-\mathrm{O}$ bond; owing to the bond in the $\mathrm{ZnO} N P s$. While the other signal, at $531.9 \mathrm{eV}$, belongs to oxygen vacancies $[49,50]$. These vacancies are generated by the presence of molecules from the organic material of the Capsicum annuum var. Anaheim extract. 


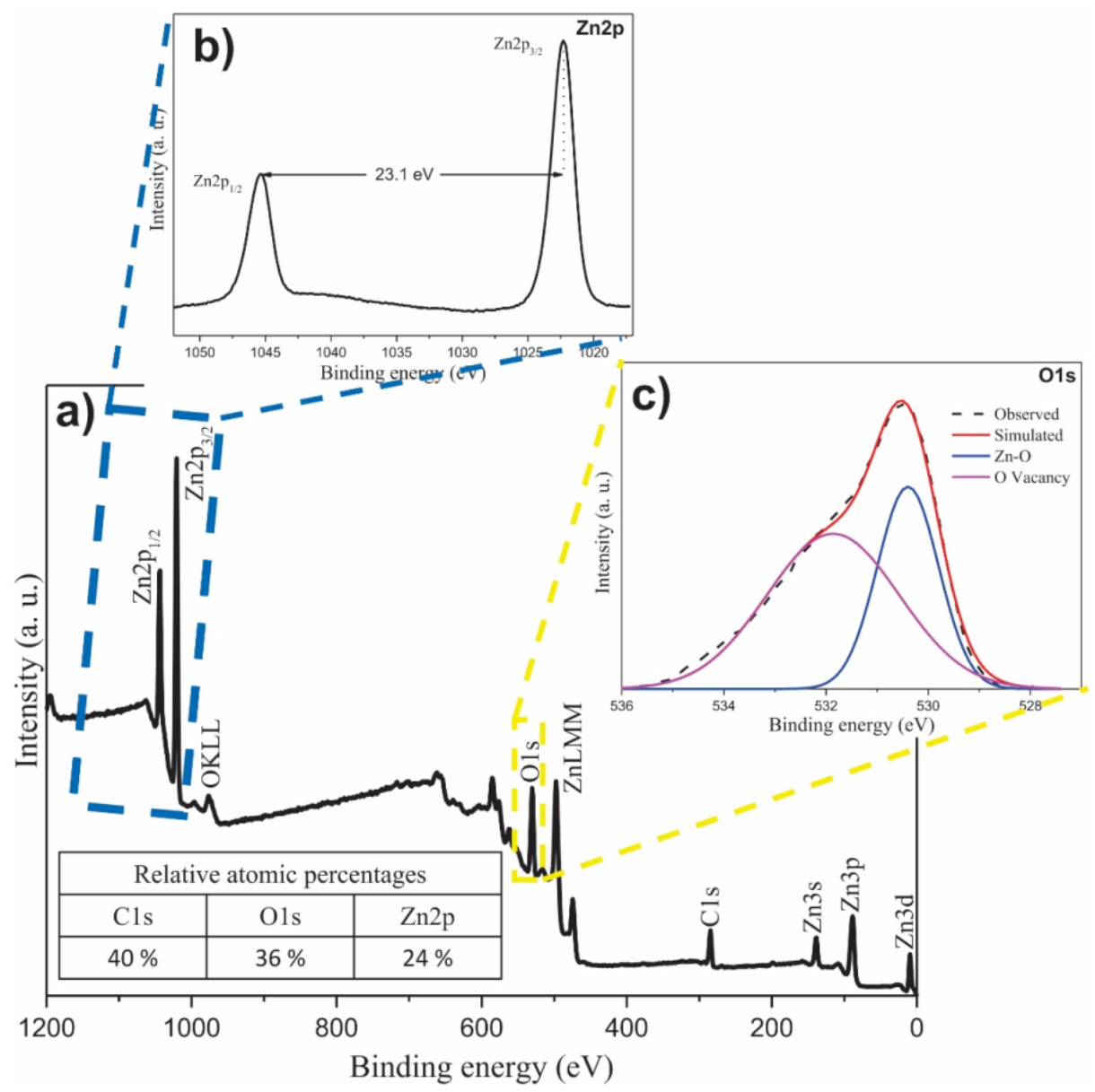

Figure 4. XPS analysis of ZnO NPs biosynthesized with Capsicum annuum var. Anaheim. (a) General spectrum (Inset: table of atomic percentages), (b) high resolution of O1s, and (c) high resolution of Zn2p.

\subsubsection{XRD}

Figure 5 shows the XRD analysis of the biosynthesized ZnO NPs. The characteristic peaks of this material are clearly observed in the diffraction pattern, identifying them at $31.74,34.38,36.22,47.55,56.54,62.81$, and $67.85^{\circ} 2 \theta$, corresponding to the Miller indexes of (100), (002), (101), (102), (110), (103), and (112), respectively. These peaks coincide with those of the JCPDS Card No. 76-0704, which describes the ZnO NPs as hexagonal structures type zincite [43]. No extra peaks were found, indicating there are no impurities. To know the crystallite size, the Debye-Scherrer formula (Equation (1)) was used in the three most intense peaks (100), (002) and (101):

$$
\mathrm{L}=\frac{\mathrm{K} \lambda}{\beta \cos \theta}
$$

where $L$ is the dimension measure of the particles, $\lambda$ the incident wavelength, $\beta$ the full width at half maximum of the peak, $\theta$ the Bragg angle, and $K$ takes the value of 0.9 [51]. The results showed that the biosynthesized NPs had an average crystallite size of $17 \mathrm{~nm}$. Different values from TEM analysis, because crystallite size is a coherent diffraction domain and is not the same as particle size (TEM), due to the presence of polycrystalline and monocrystalline aggregates [52]. The size obtained in this study is within the range of previous reports in the literature for $\mathrm{ZnO}$ NPs [21,53]. 


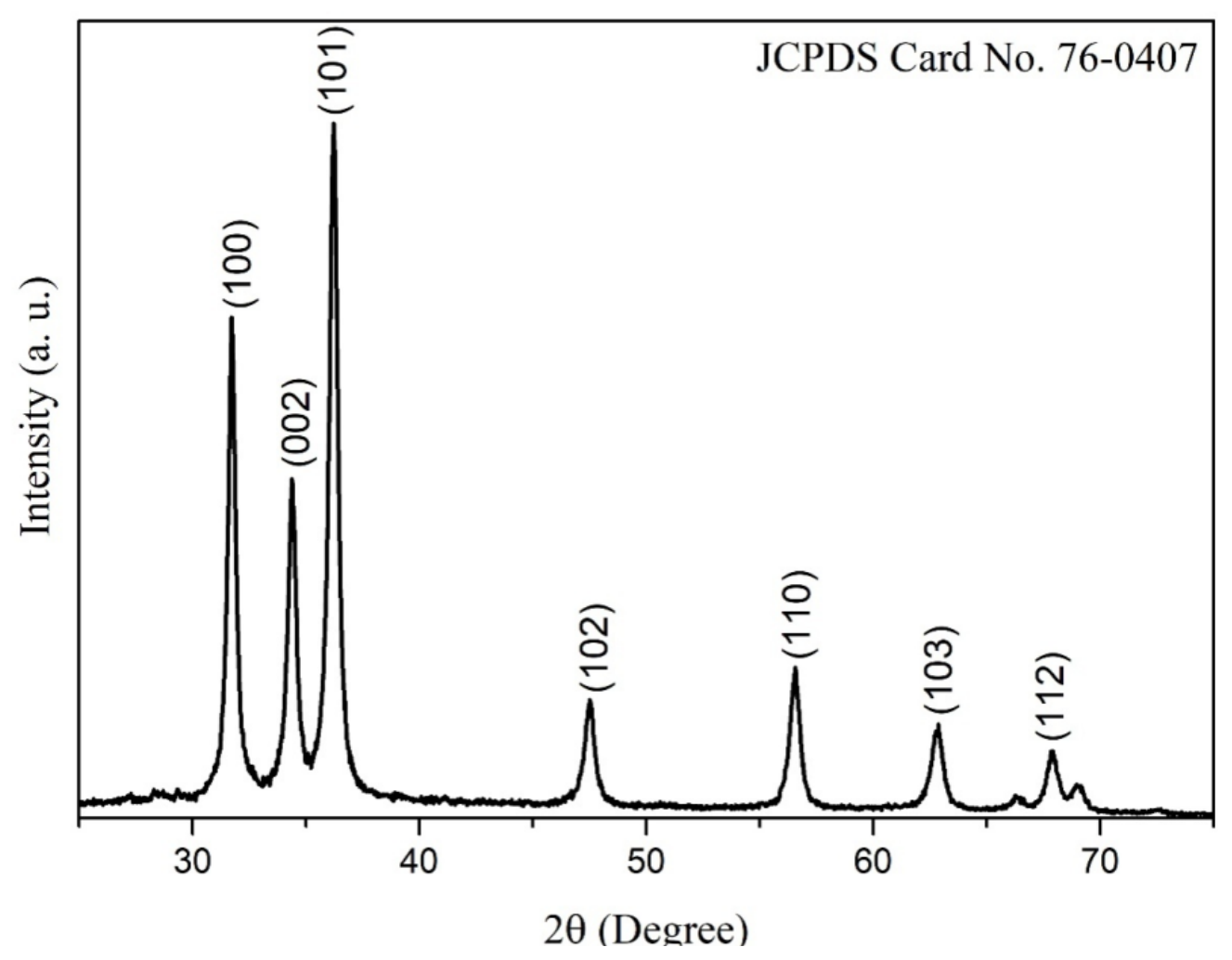

Figure 5. XRD of ZnO NPs biosynthesized with Capsicum annuum var. Anaheim.

In this work, Rietveld refinement was performed with High Score Plus software on XRD patterns. The results of the Rietveld refinement disclosed a zincite phase of a hexagonal structure with crystallite strain of 0.38 and cell volume of $47.81 \AA^{3}$, obtaining a goodness of fit (GOF) adjustment of 2.88. The parameters obtained coincide with that reported in literature [54,55], these results confirm the obtaining of the NPs of $\mathrm{ZnO}$ in zincite phase. Table 1 shows the parameters obtained from Rietveld refinement.

Table 1. Results of Rietveld refinement for the $\mathrm{ZnO}$ structure.

\begin{tabular}{|c|c|c|c|c|c|c|c|}
\hline Phase & Crystal Structure & Space Group & Latice Parameter & $\varepsilon(\%)$ & Density $\left(\mathrm{g} / \mathrm{cm}^{3}\right)$ & Cell Volume $\left(\AA^{3}\right)$ & R Factors (\%) \\
\hline Zincite & Hexagonal & P $63 \mathrm{~m} \mathrm{c}$ & $\begin{array}{c}\mathrm{a}=3.25 \AA \\
\mathrm{b}=3.25 \AA \\
\mathrm{c}=5.21 \AA \\
\mathrm{c} / \mathrm{a}=1.60 \\
\alpha=90^{\circ} \\
\beta=90^{\circ} \\
\gamma=120^{\circ}\end{array}$ & 0.379 & 5.65 & 47.81 & $\begin{array}{c}R_{\exp }=6.97 \\
R_{p}=15.97 \\
R_{w p}=20.10 \\
G O F=2.88\end{array}$ \\
\hline
\end{tabular}

\subsubsection{PL}

The spectrum of PL was performed in a wavelength range from 385 to $700 \mathrm{~nm}$ with a $\lambda_{\text {ex }}$ of $350 \mathrm{~nm}$, as is observed in Figure 6. A sharp and well-defined ultraviolet emission can be observed in the spectrum, and a very wide visible emission. This is due to the microstructure of $\mathrm{ZnO} N P s$, since a change in particle size is related to the change in optical properties [56]. At approximately $400 \mathrm{~nm}$, a peak that corresponds to the emission of the near band edge is observed, which is attributed to the direct recombination of free excitons in the ZnO NPs. On the other hand, in the visible emission zone (425 to 675), the emission of defects in the $\mathrm{ZnO}$ network occurs, such as interstitial defects of $\mathrm{Zn}$ and oxygen vacancies [57]. 


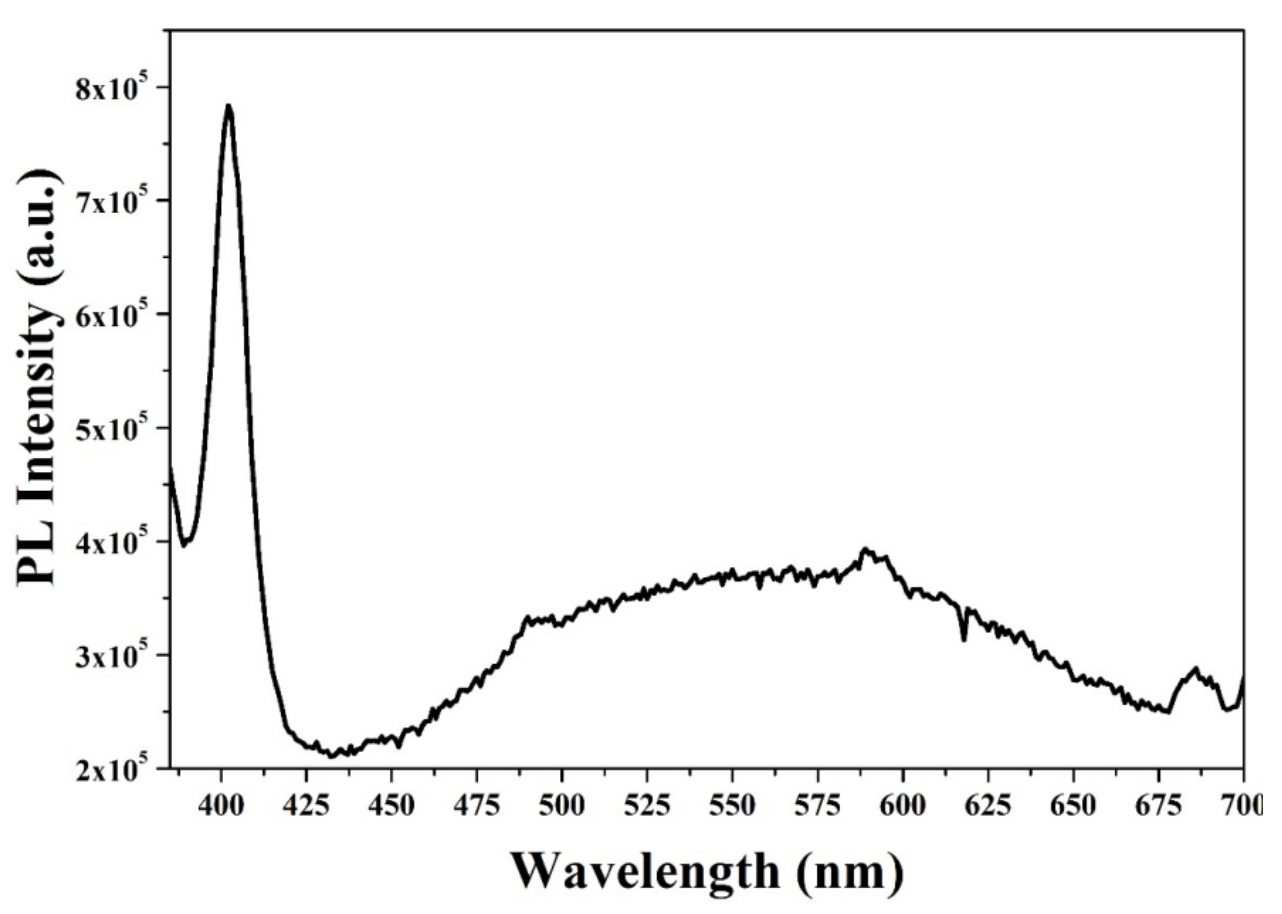

Figure 6. PL spectrum of ZnO NPs biosynthesized with Capsicum annuum var. Anaheim.

\subsubsection{UV-Vis (Band-Gap)}

By studying the absorbance of the biosynthesized ZnO NPs, assayed in the UV-Vis spectrum, the energy required to make an electron jump from its valence band to the conduction band in these NPs was determined. The band-gap study was carried out following the TAUC model (Equation (2)).

$$
(\propto \mathrm{h} v)^{\frac{1}{n}}=\mathrm{B}\left(\mathrm{h} v-\mathrm{E}_{\mathrm{g}}\right)
$$

where $\alpha(v)$ corresponds to the absorption coefficient (Lambert-Beer), $\mathrm{h} v$ is equal to the energy of the incident photon, $B$ is a constant, $E_{g}$ is the band-gap energy, and, finally, the value of " $n$ " corresponds to the type of electronic transition $n=1 / 2$ [58]. The value depicted / from the band-gap corresponding to the Capsicum annuum var. Anaheim biosynthesized $\mathrm{ZnO}$ NPs was $2.93 \mathrm{eV}$, which can be seen in Figure 7, lower than the value reported for conventional ZnO NPs [59]. This means the constituents of Capsicum annuum var. Anaheim extract work as photosensitizers [60], which reveals that they can be used in photocatalysis processes to eliminate contaminants in water. Similar values have been previously reported in the literature [61]. The absorbance spectrum of the biosynthesized ZnO NPs can be observed in the inset of Figure 7, which presents a band with $\lambda_{\max }$ at $370 \mathrm{~nm}$. This band has been assigned in previous reports as characteristic of ZnO NPs [62,63]. As in ATR-IR and XRD, this indicates a successful synthesis of ZnO NPs.

\subsection{Formation Mechanism}

Based on the characterization studies carried out on the biosynthesized NPs, a proposal for the formation mechanism of the NPs is made. The formation scheme is shown in Figure 8. Considering that the extract of Capsicum annuum var. Anaheim is a source rich in vitamins, carotenoids, flavonoids, etc. [64], the most accepted mechanism suggests that, when zinc nitrate is in solution with the extract, the $\mathrm{Zn}^{2+}$ ions are uniformly distributed [65]. In the process, as the $\mathrm{Zn}^{2+}$ ions are in direct interaction with the $\mathrm{OH}$ groups of the biomolecules in the extract, the biomolecules work as electron donors, donating their electrons to the electrophilic $\mathrm{Zn}^{2+}$ species, leading to the oxidation of the hydroxyl groups and the reduction of the $\mathrm{Zn}^{2+}$ ions [66]. Through this interaction, a link is generated 
between the $\mathrm{Zn}^{2+}$ ions and the biomolecules to form a stable complex [67]. Subsequently, the formation of $\mathrm{ZnO}$ NPs occurs when subjected to heat treatment [68]. The formation of the $\mathrm{ZnO}$ NPs by the effect of the biomolecules within the extract indicates that the biomolecules act as capping and chelating agents [69].

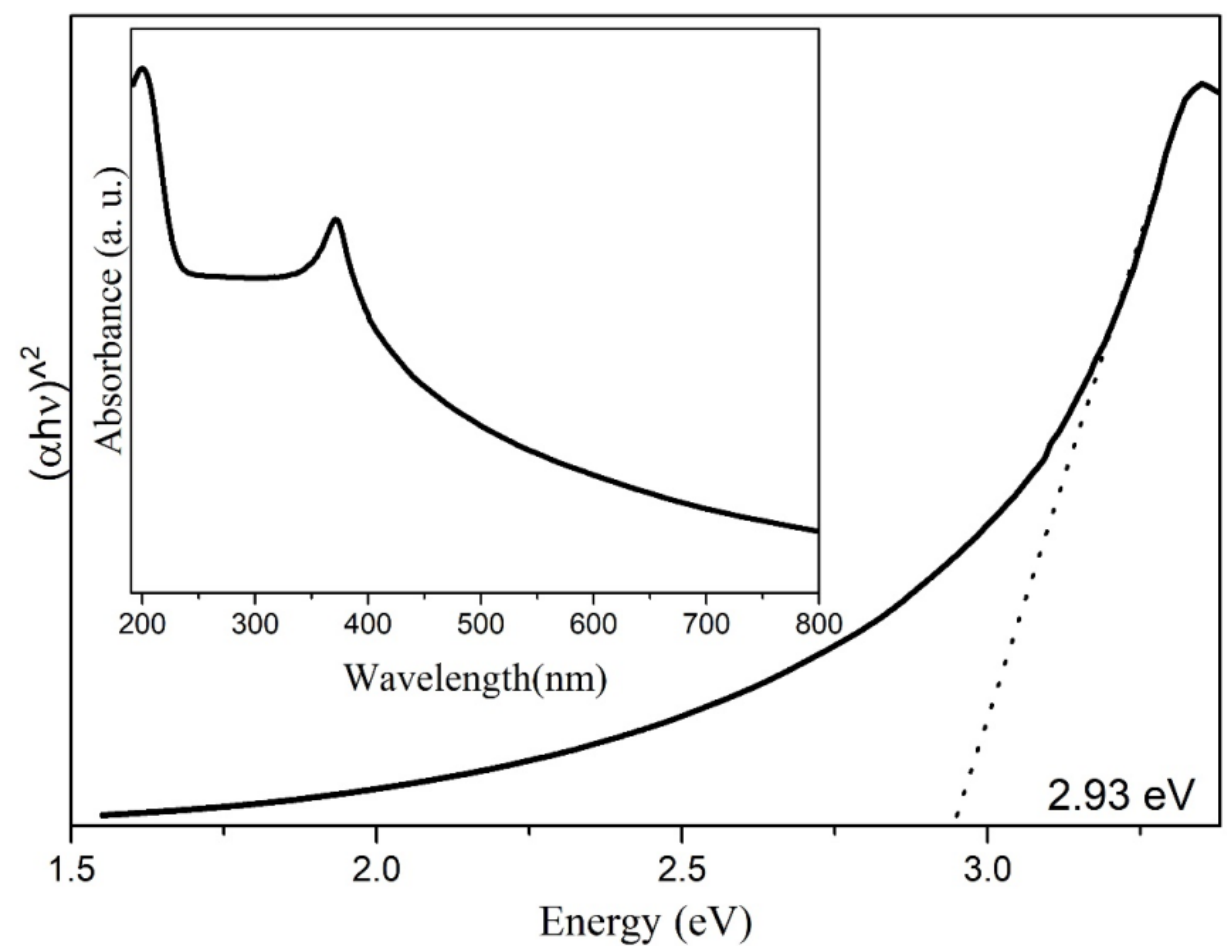

Figure 7. TAUC graph (Inset: UV-Vis absorbance spectrum) of ZnO NPs biosynthesized with Capsicum annuum var. Anaheim.
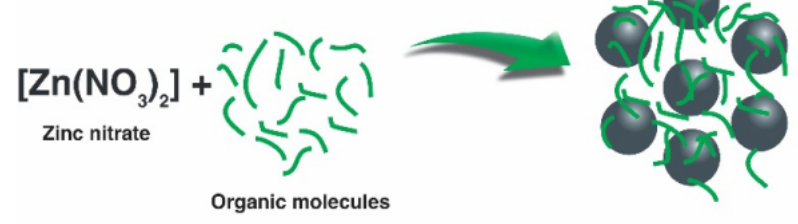

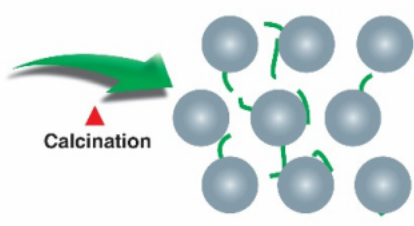

Organic molecules
$\mathrm{Zn}(\mathrm{OH})_{2}$
$\mathrm{ZnONPs}$

Figure 8. Proposed formation mechanism for ZnO NPs biosynthesized with Capsicum annuum var. Anaheim.

\subsection{Photocatalytic Activity}

In addition to using an ecological route for the synthesis of ZnO NPs, its application in the elimination of pollutants in water significantly helps to solve environmental problems worldwide. The photocatalytic study in the elimination of three organic dyes (MB, MO and $\mathrm{RhB}$ ) is observed in Figure 9. The absorption bands of greater intensity of $\mathrm{MB}, \mathrm{MO}$, and $\mathrm{RhB}$ are found at 664,470 , and $550 \mathrm{~nm}$, respectively [70,71]. The initial concentration of the pollutants marked the starting point of the measurements. It should be noted that, in Figure $9 \mathrm{a}-\mathrm{c}$, as the exposure time in UV light increases, the concentration decreases markedly. On the other hand, Figure $9 \mathrm{~d}$ presents the complete degradation study, showing that the three dyes presented as light decrease in concentration after $30 \mathrm{~min}$ of stirring in darkness (approximately 1\%). This occurs by the adsorption process due to NPs-dye affinity [20]. These graphs show that the photocatalyst accelerated the MB degradation 
process, achieving $100 \%$ degradation in approximately one hour of exposure (60 $\mathrm{min}$ ). In $180 \mathrm{~min}, 85 \%$ of the $\mathrm{MO}$ was degraded. For the RhB pollutant, its degradation was $92 \%$ in $180 \mathrm{~min}$. This data corroborates the inset shown in Figure 9d, which depicts the highest degradation rate constant, 0.064 , as that of the MB solution. It is reported in the literature that natural degradation of these pollutants is around several hours of exposure [72-74]. Additionally, Table 2 shows other results reported in the literature. This indicates that the Capsicum annuиm var. Anaheim biosynthesized $\mathrm{ZnO}$ NPs are very useful for accelerating the degradation of these organic colorants in water.
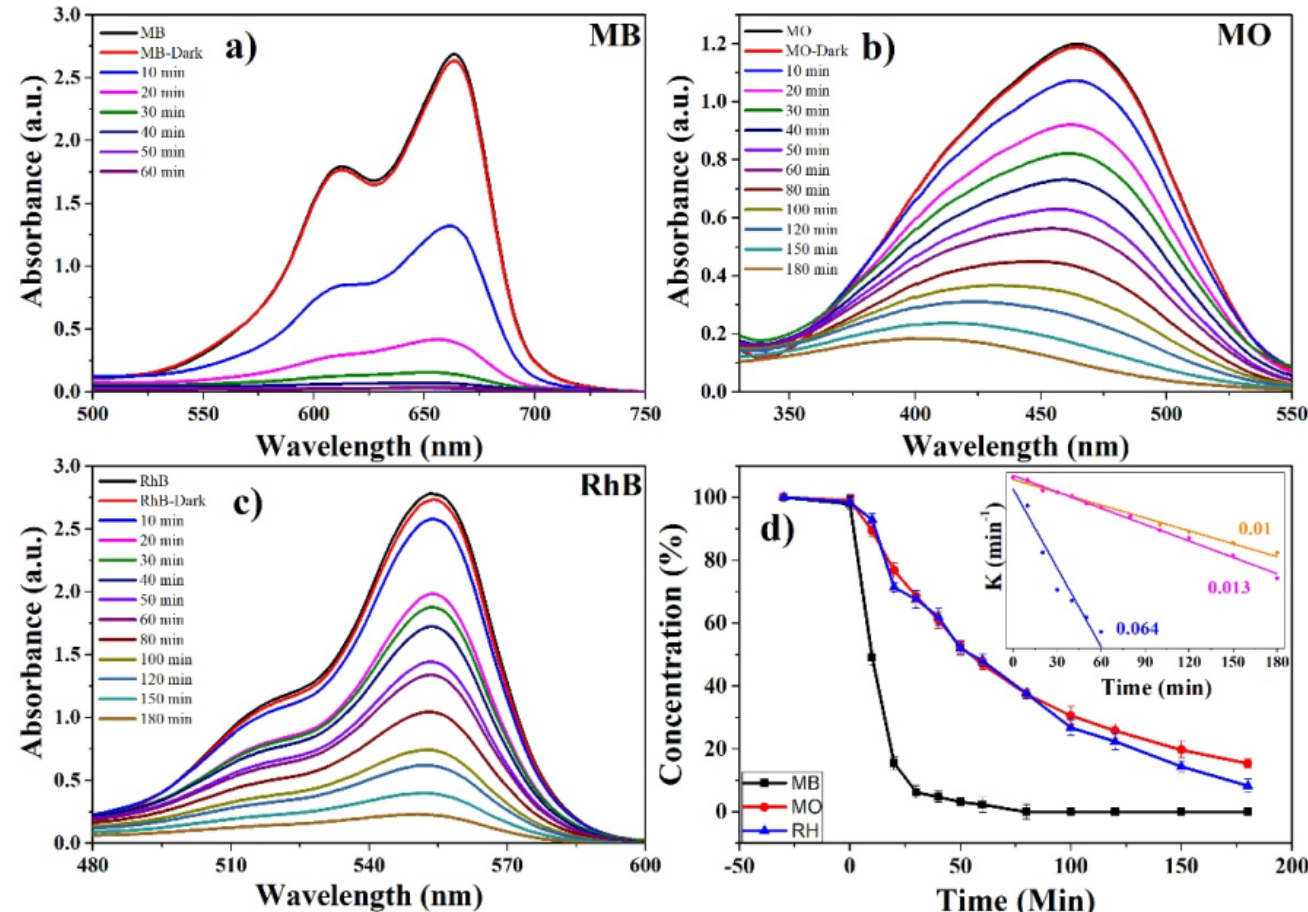

Figure 9. Photocatalytic study: (a) UV-Vis of MB, (b) UV-Vis of MO, (c) UV-Vis of RhB and (d) complete study of degradation of organic dyes using ZnO NPs biosynthesized with Capsicum annuum var. Anaheim.

Table 2. Photocatalytic activity of $\mathrm{ZnO}$ nanoparticles from some literature reports.

\begin{tabular}{|c|c|c|c|c|c|c|}
\hline Year & NPs & Synthesis & NPs Size (nm) & Pollutant & $\begin{array}{c}\text { Degradation } \\
\text { Time }\end{array}$ & Reference \\
\hline 2021 & $\mathrm{ZnO}$ & Green synthesis & 40 & MB & $100 \%$ in $60 \mathrm{~min}$ & This work \\
\hline 2021 & $\mathrm{ZnO}$ & Green synthesis & 40 & $\mathrm{MO}$ & $85 \%$ in $180 \mathrm{~min}$ & This work \\
\hline 2021 & $\mathrm{ZnO}$ & Green synthesis & 40 & $\mathrm{RhB}$ & $92 \%$ in $180 \mathrm{~min}$ & This work \\
\hline 2020 & $\mathrm{ZnO}$ & Green synthesis & 50 & MB & $55 \%$ in $200 \mathrm{~min}$ & [26] \\
\hline 2020 & $\mathrm{Ag} / \mathrm{ZnO}$ & Amino acid assisted synthesis & $\sim 20-50$ & MB & 85 in $210 \mathrm{~min}$ & [75] \\
\hline 2020 & $\mathrm{ZnO}$ & Green synthesis & $30-50$ & MB & $92 \%$ in $150 \mathrm{~min}$ & [76] \\
\hline 2020 & Nanoflowers $\mathrm{ZnO}$ & Precipitation method & $20-35$ & $\mathrm{MO}$ & $100 \%$ in $\sim 240 \mathrm{~min}$ & [77] \\
\hline 2020 & $\mathrm{ZnO}: \mathrm{CuO}$ & Green synthesis & $\sim 20-30$ & $\mathrm{MO}$ & $45 \%$ in $60 \mathrm{~min}$ & [78] \\
\hline 2020 & $\mathrm{Au}-\mathrm{ZnO}$ & Green synthesis & 33 & $\operatorname{RhB}$ & $74 \%$ in $180 \mathrm{~min}$ & [62] \\
\hline 2020 & $\mathrm{ZnO}$ & Green synthesis & $60-120$ & $\mathrm{RhB}$ & $85 \%$ in $140 \mathrm{~min}$ & [79] \\
\hline
\end{tabular}

For a more in-depth analysis of the photocatalytic degradation process for the three colorants, the turnover frequency (TOF) calculation was performed to estimate the number of molecules that were degraded, as well as the number of catalytic cycles during pho- 
tocatalytic degradation per unit of time [27]. The TOF was obtained with the model of Equation (3):

$$
\mathrm{TOF}=\frac{(\text { conversion } \%)(\text { Number of moles of substrate })}{(\text { Number of moles of catalyst })(\text { Time })}
$$

where the conversion \% is the degradation achieved by the photocatalyst. The results obtained are shown in Figure 10, where values of $6.36 \times 10^{-3}, 1.76 \times 10^{-3}$, and $1.30 \times 10^{-3}$ for $\mathrm{MB}, \mathrm{MO}$, and $\mathrm{RhB}$, respectively, can be observed. The highest TOF value achieved is that for $\mathrm{MB}$, which is several times higher than the $\mathrm{MO}$ and RhB values, likewise regarding the degradation constants $\mathrm{k}$. These values are outstanding in comparison with other photocatalytic systems reported in literature [80-82].

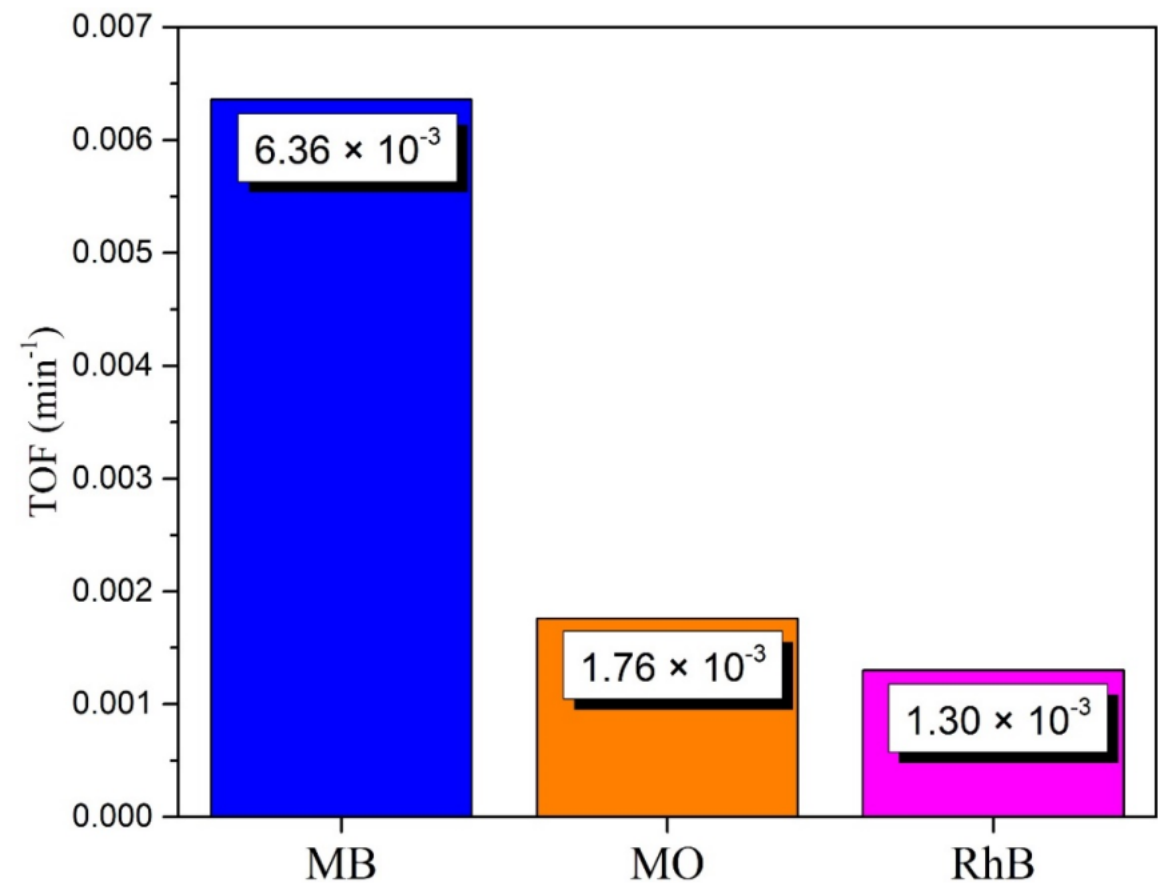

Figure 10. TOF achieved in photocatalytic degradation of MB, MO, and RhB using ZnO NPs biosynthesized with Capsicum annuum var. Anaheim.

\subsection{Photodegradation Mechanism}

Figure 11 describes a degradation mechanism of the dyes analyzed in this investigation, $\mathrm{MB}, \mathrm{MO}$, and $\mathrm{RhB}$. The degradation of the dyes begins with the adsorption of the dye on the surface of the NPs due to the affinity that exists between them [83]. Once the molecules have been adsorbed, they are irradiated with ultraviolet light between 3.1 and $6.2 \mathrm{eV}$; an energy greater than the band-gap of the ZnO NPs biosynthesized with Capsicum annuum var. (2.93 eV). With this irradiation, an electron excitation occurs in the valence band $(\mathrm{VB})$, which subsequently passes to the conduction band $(\mathrm{CB})$, giving rise to the generation of an electron-hole pair [76]. When this occurs, the photoexcited electrons interact with molecular oxygen $\left(\mathrm{O}_{2}\right)$, generating superoxide radicals $\left(\mathrm{O}_{2}^{*}\right)$, while the holes interact with water molecules to generate hydroxyl radicals $\left(\mathrm{OH}^{-}\right)$[84]. The $\mathrm{O}_{2}^{*}$ and $\mathrm{OH}^{-}$ radicals are both species with very high oxidation coefficients [85]; therefore, when these radicals interact with the molecules of the dyes, they cause the degradation of the initial molecules generating by-products. The proposal shown in Figure 11 was made based on the literature. In the case of $\mathrm{MB}$, the $\mathrm{O}_{2}^{*}$ and $\mathrm{OH}^{-}$radicals interact with the $\mathrm{S}$ atoms of the $\mathrm{C}-\mathrm{S}^{+}=\mathrm{C}$ group and reduce the $\mathrm{C}=\mathrm{N}$ bond. Subsequently, some demethylation and dechlorination processes occur, obtaining $\mathrm{CO}_{2}, \mathrm{H}_{2} \mathrm{O}$, and some mineral species as by-products [86-88]. On the other hand, the photocatalytic degradation of MO begins with the breaking of the $\mathrm{N}=\mathrm{N}$ bond, causing the separation of the molecule. The radicals 
then attack the $\mathrm{CH}_{3}-\mathrm{N}-\mathrm{CH}_{3}$ group, decomposing the $\mathrm{CH}_{3}$ group. Subsequently, one of the aromatic rings is released, and some intermediate steps take place, to generate the final by-products, such as $\mathrm{CO}_{2}$ and $\mathrm{H}_{2} \mathrm{O}$ [89-91]. Finally, the RhB degradation process begins when the double bond of the unsaturated chromophore is attacked by the $\mathrm{O}_{2}^{*}$ and $\mathrm{OH}^{-}$radicals until it is broken. Subsequently, there is the consecutive elimination of the ethyl groups, and other intermediate steps, such as the opening of aromatic rings and mineralization. In the end, $\mathrm{CO}_{2}$ and $\mathrm{H}_{2} \mathrm{O}$ are obtained [92-94].

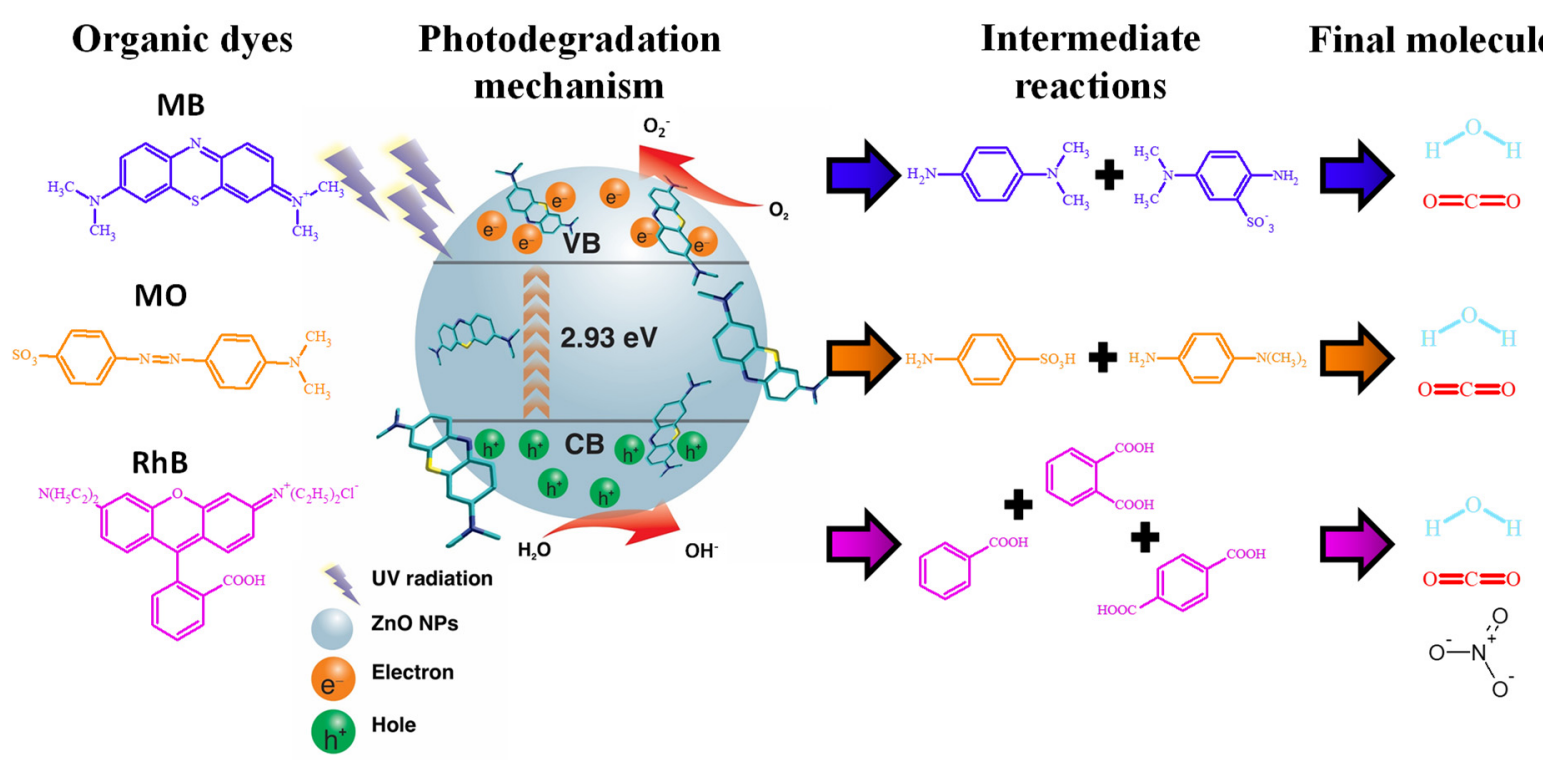

Figure 11. Photocatalytic degradation mechanism of $\mathrm{MB}, \mathrm{MO}$ and $\mathrm{RhB}$.

\section{Conclusions}

Obtaining ZnO NP through green synthesis using Anaheim chili (Capsicum annuum var. Anaheim) was successful. Using this ecological method, ZnO NPs were obtained with an average size of $40 \mathrm{~nm}$, a zincite-type crystalline structure, and a $2.93 \mathrm{eV}$ bandgap. This indicates that using materials from nature (green synthesis) is an effective route for the generation of semiconductor nanoparticles, with average sizes smaller than $100 \mathrm{~nm}$. Furthermore, the use of ZnO NPs contributes directly to the worldwide problem of water pollution. The application of $\mathrm{ZnO} N$ Ps present excellent photocatalytic properties, managing to degrade $100 \%$ of the MB organic dye in $60 \mathrm{~min}$. In addition, they was able to degrade $85 \%$ of $\mathrm{MO}$ in $180 \mathrm{~min}$, and $92 \%$ of $\mathrm{RhB}$ in $180 \mathrm{~min}$. The range of applications of these nanoparticles could be very wide, considering that they are excellent catalysts in the elimination of contaminants present in water. ZnO NPs biosynthesized with Capsicum annuum var. Anaheim could be employed in removing various pollutants present in rivers, streams, and seas around the world.

Author Contributions: P.A.L.-M.: Conceptualization, Investigation, Methodology and Writing Review and Editing. A.L.-P.: Methodology, Formal Analysis and Writing Original Draft. O.J.N.-O.: Methodology, Investigation and Writing Original Draft. G.A.-P.: Formal Analysis, Visualization and Methodology. Y.A.B.-L.: Formal Analysis and Writing Review and Editing. V.M.O.-C.: Investigation, Resources and Visualization, H.E.G.-G.: Conceptualization, Supervision and Validation and M.d.J.C.-C.: Conceptualization, Supervision, Validation and Writing Review and Editing. All authors have read and agreed to the published version of the manuscript.

Funding: This research received no external funding.

Institutional Review Board Statement: Not applicable.

Informed Consent Statement: Not applicable.

Data Availability Statement: Not applicable. 
Acknowledgments: Authors thank to CONACYT for the projects No. 295075 Infraestructure and No. 4940 National Problems, to the Universidad Autónoma de Baja California for project number 676 and we gratefully acknowledge the use of TEM facilities at the TEM Laboratory of Universidad de Sonora.

Conflicts of Interest: The authors declare no conflict of interest.

\section{References}

1. Zhang, Y.; Liang, J.; Zeng, G.; Tang, W.; Lu, Y.; Luo, Y.; Xing, W.; Tang, N.; Ye, S.; Li, X.; et al. How climate change and eutrophication interact with microplastic pollution and sediment resuspension in shallow lakes: A review. Sci. Total Environ. 2020, 705, 135979. [CrossRef] [PubMed]

2. Zheng, Y.; Zheng, L.; Zhan, Y.; Lin, X.; Zheng, Q.; Wei, K. Ag/ZnO Heterostructure Nanocrystals: Synthesis, Characterization, and Photocatalysis. Inorg. Chem. 2007, 46, 6980-6986. [CrossRef] [PubMed]

3. Shalla, A.H.; Bhat, M.A.; Yaseen, Z. Hydrogels for removal of recalcitrant organic dyes: A conceptual overview. J. Environ. Chem. Eng. 2018, 6, 5938-5949. [CrossRef]

4. Berradi, M.; Hsissou, R.; Khudhair, M.; Assouag, M.; Cherkaoui, O.; El Bachiri, A.; El Harfi, A. Textile finishing dyes and their impact on aquatic environs. Heliyon 2019, 5, e02711. [CrossRef]

5. Shim, Y.J.; Soshnikova, V.; Anandapadmanaban, G.; Mathiyalagan, R.; Jimenez Perez, Z.E.; Markus, J.; Ju Kim, Y.; Castro-Aceituno, V.; Yang, D.C. Zinc oxide nanoparticles synthesized by Suaeda japonica Makino and their photocatalytic degradation of methylene blue. Optik 2019, 182, 1015-1020. [CrossRef]

6. Arya, G.; Sharma, N.; Ahmed, J.; Gupta, N.; Kumar, A.; Chandra, R.; Nimesh, S. Degradation of anthropogenic pollutant and organic dyes by biosynthesized silver nano-catalyst from Cicer arietinum leaves. J. Photochem. Photobiol. B Biol. 2017, 174, 90-96. [CrossRef]

7. Sponza, A.D.; Fernandez, N.J.; Yang, D.; Ortiz, K.A.; Navarro, A.E. Comparative sorption of methylene blue onto hydrophobic clays. Environments 2015, 2, 388-398. [CrossRef]

8. Rabbani, F.; Shaikh, A.J.; Khan, J.; Ajaz, H.; Rafique, M.; Khan, Z.U.H.; Ali, Z.; Hussain, H.; Gillani, M.M.; Aslam, K.; et al. Removal of Organic Colorants Using Nano Copper Antimony Oxychloride Synthesized by Non-solvated System. J. Inorg. Organomet. Polym. Mater. 2019, 29, 893-900. [CrossRef]

9. Udayabhanu; Nagaraju, G.; Nagabhushana, H.; Suresh, D.; Anupama, C.; Raghu, G.K.; Sharma, S.C. Vitis labruska skin extract assisted green synthesis of $\mathrm{ZnO}$ super structures for multifunctional applications. Ceram. Int. 2017, 43, 11656-11667. [CrossRef]

10. Yin, J.; Roso, M.; Boaretti, C.; Lorenzetti, A.; Martucci, A.; Modesti, M. PVDF-TiO 2 core-shell fibrous membranes by microwavehydrothermal method: Preparation, characterization, and photocatalytic activity. J. Environ. Chem. Eng. 2021, 9, 106250. [CrossRef]

11. Al-Gharibi, M.A.; Kyaw, H.H.; Al-Sabahi, J.N.; Zar Myint, M.T.; Al-Sharji, Z.A.; Al-Abri, M.Z. Silver nanoparticles decorated zinc oxide nanorods supported catalyst for photocatalytic degradation of paracetamol. Mater. Sci. Semicond. Process. 2021, 134, 105994. [CrossRef]

12. Yusoff, N.; Ho, L.-N.; Ong, S.-A.; Wong, Y.-S.; Khalik, W. Photocatalytic activity of zinc oxide (ZnO) synthesized through different methods. Desalination Water Treat. 2016, 57, 12496-12507. [CrossRef]

13. Liu, J.; Wang, P.; Fan, J.; Yu, H. Carbon-coated cubic-phase molybdenum carbide nanoparticle for enhanced photocatalytic H2-evolution performance of $\mathrm{TiO}_{2}$. J. Energy Chem. 2020, 51, 253-261. [CrossRef]

14. Luque, P.A.; Nava, O.; Soto-Robles, C.A.; Chinchillas-Chinchillas, M.J.; Garrafa-Galvez, H.E.; Baez-Lopez, Y.A.; Valdez-Núñez, K.P.; Vilchis-Nestor, A.R.; Castro-Beltrán, A. Improved photocatalytic efficiency of $\mathrm{SnO}_{2}$ nanoparticles through green synthesis. Optik 2020, 206, 164299. [CrossRef]

15. Ibrahim, Y.O.; Gondal, M.A.; Alaswad, A.; Moqbel, R.A.; Hassan, M.; Cevik, E.; Qahtan, T.F.; Dastageer, M.A.; Bozkurt, A. Laser-induced anchoring of $\mathrm{WO}_{3}$ nanoparticles on reduced graphene oxide sheets for photocatalytic water decontamination and energy storage. Ceram. Int. 2020, 46, 444-451. [CrossRef]

16. Qi, K.; Xing, X.; Zada, A.; Li, M.; Wang, Q.; Liu, S.; Lin, H.; Wang, G. Transition metal doped ZnO nanoparticles with enhanced photocatalytic and antibacterial performances: Experimental and DFT studies. Ceram. Int. 2020, 46, 1494-1502. [CrossRef]

17. Molkenova, A.; Sarsenov, S.; Atabaev, S.; Khamkhash, L.; Atabaev, T.S. Hierarchically-structured hollow CuO microparticles for efficient photo-degradation of a model pollutant dye under the solar light illumination. Environ. Nanotechnol. Monit. Manag. 2021, 16, 100507. [CrossRef]

18. Belaidi, S.; Sangare, S.; Felahi, A.; Remache, W.; Belattar, S.; Sehili, T. Synthesis of metal and non-metal doping hematite nanoparticles for adsorption and photocatalytic degradation of acid red 14 in aqueous solutions. Int. J. Environ. Anal. Chem. 2021, 1-14. [CrossRef]

19. Theerthagiri, J.; Salla, S.; Senthil, R.A.; Nithyadharseni, P.; Madankumar, A.; Arunachalam, P.; Maiyalagan, T.; Kim, H.-S. A review on (ZnO) nanostructured materials: Energy, environmental and biological applications. Nanotechnology 2019, $30,392001$. [CrossRef]

20. Siva, N.; Sakthi, D.; Ragupathy, S.; Arun, V.; Kannadasan, N. Synthesis, structural, optical and photocatalytic behavior of Sn doped ZnO nanoparticles. Mater. Sci. Eng. B 2020, 253, 114497. [CrossRef] 
21. Pillai, A.M.; Sivasankarapillai, V.S.; Rahdar, A.; Joseph, J.; Sadeghfar, F.; Anuf, A.R.; Rajesh, K.; Kyzas, G.Z. Green synthesis and characterization of zinc oxide nanoparticles with antibacterial and antifungal activity. J. Mol. Struct. 2020, $1211,128107$. [CrossRef]

22. Kołodziejczak-Radzimska, A.; Jesionowski, T. Zinc Oxide-From Synthesis to Application: A Review. Materials 2014, 7, $2833-2881$. [CrossRef] [PubMed]

23. Wojnarowicz, J.; Chudoba, T.; Lojkowski, W. A Review of Microwave Synthesis of Zinc Oxide Nanomaterials: Reactants, Process Parameters and Morphologies. Nanomaterials 2020, 10, 1086. [CrossRef] [PubMed]

24. Naveed Ul Haq, A.; Nadhman, A.; Ullah, I.; Mustafa, G.; Yasinzai, M.; Khan, I. Synthesis Approaches of Zinc Oxide Nanoparticles: The Dilemma of Ecotoxicity. J. Nanomater. 2017, 2017, 8510342. [CrossRef]

25. Doan Thi, T.U.; Nguyen, T.T.; Thi, Y.D.; Ta Thi, K.H.; Phan, B.T.; Pham, K.N. Green synthesis of ZnO nanoparticles using orange fruit peel extract for antibacterial activities. RSC Adv. 2020, 10, 23899-23907. [CrossRef]

26. Shabaani, M.; Rahaiee, S.; Zare, M.; Jafari, S.M. Green synthesis of ZnO nanoparticles using loquat seed extract; Biological functions and photocatalytic degradation properties. LWT 2020, 134, 110133. [CrossRef]

27. Luque, P.A.; Chinchillas-Chinchillas, M.J.; Nava, O.; Lugo-Medina, E.; Martínez-Rosas, M.E.; Carrillo-Castillo, A.; Vilchis-Nestor, A.R.; Madrigal-Muñoz, L.E.; Garrafa-Gálvez, H.E. Green synthesis of tin dioxide nanoparticles using Camellia sinensis and its application in photocatalytic degradation of textile dyes. Optik 2021, 229, 166259. [CrossRef]

28. Nabi, G.; Ain, Q.-U.; Tahir, M.B.; Nadeem Riaz, K.; Iqbal, T.; Rafique, M.; Hussain, S.; Raza, W.; Aslam, I.; Rizwan, M. Green synthesis of $\mathrm{TiO}_{2}$ nanoparticles using lemon peel extract: Their optical and photocatalytic properties. Int. J. Environ. Anal. Chem. 2020, 1-9. [CrossRef]

29. Velsankar, K.; Aswin Kumar, R.M.; Preethi, R.; Muthulakshmi, V.; Sudhahar, S. Green synthesis of CuO nanoparticles via Allium sativum extract and its characterizations on antimicrobial, antioxidant, antilarvicidal activities. J. Environ. Chem. Eng. 2020, 8 , 104123. [CrossRef]

30. Aravind, M.; Ahmad, A.; Ahmad, I.; Amalanathan, M.; Naseem, K.; Mary, S.M.M.; Parvathiraja, C.; Hussain, S.; Algarni, T.S.; Pervaiz, M.; et al. Critical green routing synthesis of silver NPs using jasmine flower extract for biological activities and photocatalytical degradation of methylene blue. J. Environ. Chem. Eng. 2021, 9, 104877. [CrossRef]

31. Shaker Ardakani, L.; Alimardani, V.; Tamaddon, A.M.; Amani, A.M.; Taghizadeh, S. Green synthesis of iron-based nanoparticles using Chlorophytum comosum leaf extract: Methyl orange dye degradation and antimicrobial properties. Heliyon 2021, 7, e06159. [CrossRef] [PubMed]

32. Rajendrachari, S.; Taslimi, P.; Karaoglanli, A.C.; Uzun, O.; Alp, E.; Jayaprakash, G.K. Photocatalytic degradation of Rhodamine B $(\mathrm{RhB})$ dye in waste water and enzymatic inhibition study using cauliflower shaped ZnO nanoparticles synthesized by a novel One-pot green synthesis method. Arab. J. Chem. 2021, 14, 103180. [CrossRef]

33. Drummer, S.; Madzimbamuto, T.; Chowdhury, M. Green Synthesis of Transition-Metal Nanoparticles and Their Oxides: A Review. Materials 2021, 14, 2700. [CrossRef]

34. Hayano-Kanashiro, C.; Gámez-Meza, N.; Medina-Juárez, L.Á. Wild Pepper Capsicum annuum L. var. glabriusculum: Taxonomy, Plant Morphology, Distribution, Genetic Diversity, Genome Sequencing, and Phytochemical Compounds. Crop Sci. 2016, 56, 2165-2179. [CrossRef]

35. Tripodi, P.; Cardi, T.; Bianchi, G.; Migliori, C.A.; Schiavi, M.; Rotino, G.L.; Lo Scalzo, R. Genetic and environmental factors underlying variation in yield performance and bioactive compound content of hot pepper varieties (Capsicum annuum) cultivated in two contrasting Italian locations. Eur. Food Res. Technol. 2018, 244, 1555-1567. [CrossRef]

36. Rajakumar, G.; Thiruvengadam, M.; Mydhili, G.; Gomathi, T.; Chung, I.-M. Green approach for synthesis of zinc oxide nanoparticles from Andrographis paniculata leaf extract and evaluation of their antioxidant, anti-diabetic, and anti-inflammatory activities. Bioprocess Biosyst. Eng. 2018, 41, 21-30. [CrossRef] [PubMed]

37. Lu, P.-J.; Fu, W.-E.; Huang, S.-C.; Lin, C.-Y.; Ho, M.-L.; Chen, Y.-P.; Cheng, H.-F. Methodology for sample preparation and size measurement of commercial ZnO nanoparticles. J. Food Drug Anal. 2018, 26, 628-636. [CrossRef]

38. Happy, A.; Soumya, M.; Venkat Kumar, S.; Rajeshkumar, S.; Sheba, R.D.; Lakshmi, T.; Deepak Nallaswamy, V. Phyto-assisted synthesis of zinc oxide nanoparticles using Cassia alata and its antibacterial activity against Escherichia coli. Biochem. Biophys. Rep. 2019, 17, 208-211. [CrossRef] [PubMed]

39. Arciniegas-Grijalba, P.A.; Patiño-Portela, M.C.; Mosquera-Sánchez, L.P.; Guerrero-Vargas, J.A.; Rodríguez-Páez, J.E. ZnO nanoparticles (ZnO-NPs) and their antifungal activity against coffee fungus Erythricium salmonicolor. Appl. Nanosci. 2017, 7 , 225-241. [CrossRef]

40. Vijayakumar, S.; Mahadevan, S.; Arulmozhi, P.; Sriram, S.; Praseetha, P.K. Green synthesis of zinc oxide nanoparticles using Atalantia monophylla leaf extracts: Characterization and antimicrobial analysis. Mater. Sci. Semicond. Process. 2018, 82, 39-45. [CrossRef]

41. Soares, V.A.; Xavier, M.J.S.; Rodrigues, E.S.; de Oliveira, C.A.; Farias, P.M.A.; Stingl, A.; Ferreira, N.S.; Silva, M.S. Green synthesis of $\mathrm{ZnO}$ nanoparticles using whey as an effective chelating agent. Mater. Lett. 2020, 259, 126853. [CrossRef]

42. Tahir, H.E.; Xiaobo, Z.; Zhihua, L.; Jiyong, S.; Zhai, X.; Wang, S.; Mariod, A.A. Rapid prediction of phenolic compounds and antioxidant activity of Sudanese honey using Raman and Fourier transform infrared (FT-IR) spectroscopy. Food Chem. 2017, 226, 202-211. [CrossRef] [PubMed] 
43. Morán-Bañuelos, S.H.; Aguilar-Rincón, V.H.; Corona-Torres, T.; Castillo-González, F.; Soto-Hernández, R.M.; Miguel-Chávez, R.S. Capsaicinoids in chile pepper landraces of Puebla, Mexico. Agrociencia 2008, 42, 807-816.

44. Nagaraju, G.; Shivaraju, G.C.; Banuprakash, G.; Rangappa, D. Photocatalytic Activity of ZnO Nanoparticles: Synthesis via Solution Combustion Method. Mater. Today Proc. 2017, 4, 11700-11705. [CrossRef]

45. Wang, C.; Fan, H.; Ren, X.; Fang, J. Room temperature synthesis and enhanced photocatalytic property of $\mathrm{CeO}_{2} / \mathrm{ZnO}$ heterostructures. Appl. Phys. A 2018, 124, 99. [CrossRef]

46. Khatami, M.; Alijani, H.Q.; Heli, H.; Sharifi, I. Rectangular shaped zinc oxide nanoparticles: Green synthesis by Stevia and its biomedical efficiency. Ceram. Int. 2018, 44, 15596-15602. [CrossRef]

47. Rambabu, K.; Bharath, G.; Banat, F.; Show, P.L. Green synthesis of zinc oxide nanoparticles using Phoenix dactylifera waste as bioreductant for effective dye degradation and antibacterial performance in wastewater treatment. J. Hazard. Mater. 2021, 402, 123560. [CrossRef] [PubMed]

48. Yi, X.Y.; Ma, C.Y.; Yuan, F.; Wang, N.; Qin, F.W.; Hu, B.C.; Zhang, Q.Y. Structural, morphological, photoluminescence and photocatalytic properties of Gd-doped ZnO films. Thin Solid Films 2017, 636, 339-345. [CrossRef]

49. Gogurla, N.; Sinha, A.K.; Santra, S.; Manna, S.; Ray, S.K. Multifunctional Au-ZnO Plasmonic Nanostructures for Enhanced UV Photodetector and Room Temperature NO Sensing Devices. Sci. Rep. 2014, 4, 6483. [CrossRef] [PubMed]

50. Sahai, A.; Goswami, N. Probing the dominance of interstitial oxygen defects in ZnO nanoparticles through structural and optical characterizations. Ceram. Int. 2014, 40, 14569-14578. [CrossRef]

51. Lim, D.J.; Marks, N.A.; Rowles, M.R. Universal Scherrer equation for graphene fragments. Carbon N. Y. 2020, 162, 475-480. [CrossRef]

52. Manikandan, B.; Endo, T.; Kaneko, S.; Murali, K.R.; John, R. Properties of sol gel synthesized ZnO nanoparticles. J. Mater. Sci. Mater. Electron. 2018, 29, 9474-9485. [CrossRef]

53. Al Abdullah, K.; Awad, S.; Zaraket, J.; Salame, C. Synthesis of ZnO Nanopowders By Using Sol-Gel and Studying Their Structural and Electrical Properties at Different Temperature. Energy Procedia 2017, 119, 565-570. [CrossRef]

54. Bhardwaj, R.; Singh, J.P.; Chae, K.H.; Goyal, N.; Gautam, S. Electronic and magnetic structure investigation of vanadium doped ZnO nanostructure. Vacuum 2018, 158, 257-262. [CrossRef]

55. Fabbiyola, S.; Sailaja, V.; Kennedy, L.J.; Bououdina, M.; Judith Vijaya, J. Optical and magnetic properties of Ni-doped ZnO nanoparticles. J. Alloys Compd. 2017, 694, 522-531. [CrossRef]

56. Dash, D.; Panda, N.R.; Sahu, D. Photoluminescence and photocatalytic properties of europium doped ZnO nanoparticles. Appl. Surf. Sci. 2019, 494, 666-674. [CrossRef]

57. Ntwaeaborwa, O.M.; Mofokeng, S.J.; Kumar, V.; Kroon, R.E. Structural, optical and photoluminescence properties of Eu ${ }^{3+}$ doped ZnO nanoparticles. Spectrochim. Acta Part A Mol. Biomol. Spectrosc. 2017, 182, 42-49. [CrossRef]

58. Singh, G.P.; Aman, A.K.; Singh, R.K.; Roy, M.K. Effect of low Co-doping on structural, optical, and magnetic performance of ZnO nanoparticles. Optik 2020, 203, 163966. [CrossRef]

59. Zhang, Y.; Xu, X. Machine learning optical band gaps of doped-ZnO films. Optik 2020, 217, 164808. [CrossRef]

60. Majumder, T.; Dhar, S.; Debnath, K.; Mondal, S.P. Role of S, N co-doped graphene quantum dots as a green photosensitizer with Ag-doped $\mathrm{ZnO}$ nanorods for improved electrochemical solar energy conversion. Mater. Res. Bull. 2017, 93, 214-222. [CrossRef]

61. El-Kemary, M.; El-Shamy, H.; El-Mehasseb, I. Photocatalytic degradation of ciprofloxacin drug in water using ZnO nanoparticles. J. Lumin. 2010, 130, 2327-2331. [CrossRef]

62. Ahmad, M.; Rehman, W.; Khan, M.M.; Qureshi, M.T.; Gul, A.; Haq, S.; Ullah, R.; Rab, A.; Menaa, F. Phytogenic fabrication of ZnO and gold decorated ZnO nanoparticles for photocatalytic degradation of Rhodamine B. J. Environ. Chem. Eng. 2021, 9, 104725. [CrossRef]

63. Samy, A.; El-Sherbiny, A.E.; Menazea, A.A. Green Synthesis of High Impact Zinc Oxide Nanoparticles. Egypt. J. Chem. 2019, 62, 29-37. [CrossRef]

64. Florentino-Ramos, E.; Villa-Ruano, N.; Hidalgo-Martínez, D.; Ramírez-Meraz, M.; Méndez-Aguilar, R.; Velásquez-Valle, R.; Zepeda-Vallejo, L.G.; Pérez-Hernández, N.; Becerra-Martínez, E. 1H NMR-based fingerprinting of eleven Mexican Capsicum annuum cultivars. Food Res. Int. 2019, 121, 12-19. [CrossRef] [PubMed]

65. Sharma, S.C. ZnO nano-flowers from Carica papaya milk: Degradation of Alizarin Red-S dye and antibacterial activity against Pseudomonas aeruginosa and Staphylococcus aureus. Optik 2016, 127, 6498-6512. [CrossRef]

66. Khalafi, T.; Buazar, F.; Ghanemi, K. Phycosynthesis and Enhanced Photocatalytic Activity of Zinc Oxide Nanoparticles toward Organosulfur Pollutants. Sci. Rep. 2019, 9, 6866. [CrossRef] [PubMed]

67. Karnan, T.; Selvakumar, S.A.S. Biosynthesis of $\mathrm{ZnO}$ nanoparticles using rambutan (Nephelium lappaceum L.) peel extract and their photocatalytic activity on methyl orange dye. J. Mol. Struct. 2016, 1125, 358-365. [CrossRef]

68. Ambika, S.; Sundrarajan, M. Antibacterial behaviour of Vitex negundo extract assisted ZnO nanoparticles against pathogenic bacteria. J. Photochem. Photobiol. B Biol. 2015, 146, 52-57. [CrossRef] [PubMed]

69. Raja, A.; Ashokkumar, S.; Pavithra Marthandam, R.; Jayachandiran, J.; Khatiwada, C.P.; Kaviyarasu, K.; Ganapathi Raman, R.; Swaminathan, M. Eco-friendly preparation of zinc oxide nanoparticles using Tabernaemontana divaricata and its photocatalytic and antimicrobial activity. J. Photochem. Photobiol. B Biol. 2018, 181, 53-58. [CrossRef] [PubMed] 
70. Jayappa, M.D.; Ramaiah, C.K.; Kumar, M.A.P.; Suresh, D.; Prabhu, A.; Devasya, R.P.; Sheikh, S. Green synthesis of zinc oxide nanoparticles from the leaf, stem and in vitro grown callus of Mussaenda frondosa L.: Characterization and their applications. Appl. Nanosci. 2020, 10, 3057-3074. [CrossRef] [PubMed]

71. Nava, O.J.; Soto-Robles, C.A.; Gómez-Gutiérrez, C.M.; Vilchis-Nestor, A.R.; Castro-Beltrán, A.; Olivas, A.; Luque, P.A. Fruit peel extract mediated green synthesis of zinc oxide nanoparticles. J. Mol. Struct. 2017, 1147, 1-6. [CrossRef]

72. Mengting, Z.; Kurniawan, T.A.; Fei, S.; Ouyang, T.; Othman, M.H.D.; Rezakazemi, M.; Shirazian, S. Applicability of $\mathrm{BaTiO}_{3}$ /graphene oxide (GO) composite for enhanced photodegradation of methylene blue (MB) in synthetic wastewater under UV-vis irradiation. Environ. Pollut. 2019, 255, 113182. [CrossRef] [PubMed]

73. Gawade, V.V.; Gavade, N.L.; Shinde, H.M.; Babar, S.B.; Kadam, A.N.; Garadkar, K.M. Green synthesis of ZnO nanoparticles by using Calotropis procera leaves for the photodegradation of methyl orange. J. Mater. Sci. Mater. Electron. 2017, 28, 14033-14039. [CrossRef]

74. Liu, G.; Liao, M.; Zhang, Z.; Wang, H.; Chen, D.; Feng, Y. Enhanced photodegradation performance of Rhodamine B with g-C3N4 modified by carbon nanotubes. Sep. Purif. Technol. 2020, 244, 116618. [CrossRef]

75. Belachew, N.; Kahsay, M.H.; Tadesse, A.; Basavaiah, K. Green synthesis of reduced graphene oxide grafted Ag/ZnO for photocatalytic abatement of methylene blue and antibacterial activities. J. Environ. Chem. Eng. 2020, 8, 104106. [CrossRef]

76. Alharthi, F.A.; Alghamdi, A.A.; Alothman, A.A.; Almarhoon, Z.M.; Alsulaiman, M.F.; Al-Zaqri, N. Green synthesis of zno nanostructures using salvadora persica leaf extract: Applications for photocatalytic degradation of methylene blue dye. Crystals 2020, 10, 441. [CrossRef]

77. Mohamed Isa, E.D.; Che Jusoh, N.W.; Hazan, R.; Shameli, K. Photocatalytic degradation of methyl orange using pullulan-mediated porous zinc oxide microflowers. Environ. Sci. Pollut. Res. 2021, 28, 5774-5785. [CrossRef]

78. Vibitha, B.V.; Anitha, B.; Tharayil, N.J. Green synthesis of ZnO: CuO nanocomposites by Aloe Barbadansis leaf extract: Structure and photo catalytic properties. AIP Conf. Proc. 2020, 2287, 20031. [CrossRef]

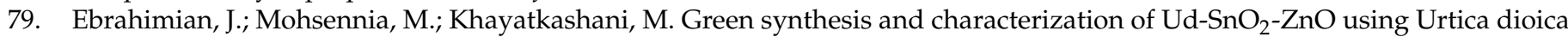
leaf extract: A nanocomposite photocatalyst for degradation of Rhodamine B dye. Res. Chem. Intermed. 2021, 47, 4789-4802. [CrossRef]

80. Luo, S.; Liu, C.; Zhou, S.; Li, W.; Ma, C.; Liu, S.; Yin, W.; Heeres, H.J.; Zheng, W.; Seshan, K.; et al. ZnO nanorod arrays assembled on activated carbon fibers for photocatalytic degradation: Characteristics and synergistic effects. Chemosphere 2020, $261,127731$. [CrossRef] [PubMed]

81. Shang, X.; Li, B.; Zhang, T.; Li, C.; Wang, X. Photocatalytic Degradation of Methyl Orange with Commercial Organic Pigment Sensitized TiO2. Procedia Environ. Sci. 2013, 18, 478-485. [CrossRef]

82. Yan, Q.; Wang, X.-Y.; Feng, J.-J.; Mei, L.-P.; Wang, A.-J. Simple fabrication of bimetallic platinum-rhodium alloyed nano-multipods: A highly effective and recyclable catalyst for reduction of 4-nitrophenol and rhodamine B. J. Colloid Interface Sci. 2021, 582, 701-710. [CrossRef] [PubMed]

83. Adeleke, J.T.; Theivasanthi, T.; Thiruppathi, M.; Swaminathan, M.; Akomolafe, T.; Alabi, A.B. Photocatalytic degradation of methylene blue by $\mathrm{ZnO} / \mathrm{NiFe}_{2} \mathrm{O}_{4}$ nanoparticles. Appl. Surf. Sci. 2018, 455, 195-200. [CrossRef]

84. Lu, J.; Ali, H.; Hurh, J.; Han, Y.; Batjikh, I.; Rupa, E.J.; Anandapadmanaban, G.; Park, J.K.; Yang, D.-C. The assessment of photocatalytic activity of zinc oxide nanoparticles from the roots of Codonopsis lanceolata synthesized by one-pot green synthesis method. Optik 2019, 184, 82-89. [CrossRef]

85. Gour, N.K.; Borthakur, K.; Paul, S.; Chandra Deka, R. Tropospheric degradation of 2-fluoropropene $\left(\mathrm{CH}_{3} \mathrm{CFCH}_{2}\right)$ initiated by hydroxyl radical: Reaction mechanisms, kinetics and atmospheric implications from DFT study. Chemosphere 2020, $238,124556$. [CrossRef]

86. He, Y.; Huang, Z.; Ma, Z.; Yao, B.; Liu, H.; Hu, L.; Zhao, Q.; Yang, Q.; Liu, D.; Du, D. Highly efficient photocatalytic performance and mechanism of $\alpha-\mathrm{ZnTcPc} / \mathrm{g}-\mathrm{C} 3 \mathrm{~N} 4$ composites for methylene blue and tetracycline degradation under visible light irradiation. Appl. Surf. Sci. 2019, 498, 143834. [CrossRef]

87. Lin, J.; Luo, Z.; Liu, J.; Li, P. Photocatalytic degradation of methylene blue in aqueous solution by using $\mathrm{ZnO}-\mathrm{SnO}_{2}$ nanocomposites. Mater. Sci. Semicond. Process. 2018, 87, 24-31. [CrossRef]

88. Luque, P.A.; Garrafa-Gálvez, H.E.; Nava, O.; Olivas, A.; Martínez-Rosas, M.E.; Vilchis-Nestor, A.R.; Villegas-Fuentes, A.; Chinchillas-Chinchillas, M.J. Efficient sunlight and UV photocatalytic degradation of Methyl Orange, Methylene Blue and Rhodamine B, using Citrus $\times$ paradisi synthesized $\mathrm{SnO}_{2}$ semiconductor nanoparticles. Ceram. Int. 2021, 47, 23861-23874. [CrossRef]

89. Skiker, R.; Zouraibi, M.; Saidi, M.; Ziat, K. Facile coprecipitation synthesis of novel $\mathrm{Bi}_{12} \mathrm{TiO}_{20} / \mathrm{BiFeO}_{3}$ heterostructure serie with enhanced photocatalytic activity for removal of methyl orange from water. J. Phys. Chem. Solids 2018, 119, 265-275. [CrossRef]

90. Salavati, H.; Teimouri, A.; Kazemi, S. Synthesis and Characterization of Novel Composite-Based Phthalocyanine Used as Efficient Photocatalyst for the Degradation of Methyl Orange. Chem. Methodol. 2017, 1, 15-31. [CrossRef]

91. Zheng, X.; Zhang, D.; Gao, Y.; Wu, Y.; Liu, Q.; Zhu, X. Synthesis and characterization of cubic Ag/ $\mathrm{TiO}_{2}$ nanocomposites for the photocatalytic degradation of methyl orange in aqueous solutions. Inorg. Chem. Commun. 2019, 110, 107589. [CrossRef]

92. Zhang, L.; Meng, Y.; Shen, H.; Li, J.; Yang, C.; Xie, B.; Xia, S. Photocatalytic degradation of rhodamine B by Bi ${ }_{2} \mathrm{O}_{3} @ L D H s ~ S-s c h e m e$ heterojunction: Performance, kinetics and mechanism. Appl. Surf. Sci. 2021, 567, 150760. [CrossRef] 
93. Zhang, Y.; Zhou, J.; Cai, W.; Zhou, J.; Li, Z. Enhanced photocatalytic performance and degradation pathway of Rhodamine B over hierarchical double-shelled zinc nickel oxide hollow sphere heterojunction. Appl. Surf. Sci. 2018, 430, 549-560. [CrossRef]

94. Wermuth, T.B.; Arcaro, S.; Venturini, J.; Hubert Ribeiro, T.M.; de Assis Lawisch Rodriguez, A.; Machado, E.L.; Franco de Oliveira, T.; Franco de Oliveira, S.E.; Baibich, M.N.; Bergmann, C.P. Microwave-synthesized $\mathrm{KNbO}_{3}$ perovskites: Photocatalytic pathway on the degradation of rhodamine B. Ceram. Int. 2019, 45, 24137-24145. [CrossRef] 